\title{
As moedas de Olímpia e a consolidação da imagética de Zeus na Grécia Clássica
}

\author{
Lilian de Angelo Laky*
}

\begin{abstract}
LAKY, L.A. As moedas de Olímpia e a consolidação da imagética de Zeus na Grécia Clássica. Revista do Museu de Arqueologia e Etnologia, São Paulo, 18: 211-237, 2008.
\end{abstract}

Resumo: Esta pesquisa objetivou estudar as imagens monetárias emitidas pelas póleis responsáveis pelo santuário de Olímpia durante os séculos V e IV a.C., época clássica. Nossa intenção foi compreender de que modo estas moedas contribuíram para a fixação figurativa de Zeus. Para tanto, comparamos as imagens de Zeus e seus atributos nestas moedas com as imagens da mesma divindade em moedas fabricadas em outras póleis e com outros tipos de suportes, especialmente esculturas e relevos. Concluiu-se que o Peloponeso foi o centro de inovação da imagética de Zeus difundindo um padrão próprio principalmente para o Ocidente grego. A sistematização do padrão de representação de Zeus nos suportes imagéticos estudados permitiu a definição de uma cronologia para a representação de Zeus nas moedas gregas e revelou um contexto histórico definido para o culto de Zeus.

Palavras-chave: Olímpia - Zeus - Iconografia monetária.

\section{Introdução}

S ituada no oeste do Peloponeso, próximo ao mar Jônico, Olímpia está localizada no vale dos rios Alfeus e Cladeus ao sul de uma colina chamada Cronos, o nome do pai de Zeus na mitologia grega. Na antiguidade grega, $\mathrm{O}$ santuário foi chamado de Altis, significando no dialeto local "arvoredo".

Olímpia teve uma importante função na ordenação da sociedade grega desde o século X

${ }^{*}$ ) Museu de Arqueologia e Etnologia da Universidade de São Paulo. Laboratório de Estudos da Cidade Antiga (labeca www.mae.usp.br/labeca). Mestranda do Programa de Pós-Graduação em Arqueologia. Bolsista do CNPq.1ilian.laky@usp.br ou IX a.C. Serviu, provavelmente, como um local neutro de encontro para os habitantes das regiões da Messênia e Arcádia, e pode assim ter tido uma função importante conservando relações inter-regionais no lado ocidental do Peloponeso (Morgan 1994: 58). De acordo com os dados arqueológicos, o santuário de Olímpia, ou a área de algum culto ali, foi muito atingido na onda de destruições que assolou a Hélade em torno de 1200 a.C., o que teria provocado um retrocesso no desenvolvimento das atividades. Foi por volta desse período, também, entre o segundo e o primeiro milênio a.C., que o povo de Élis (como foram chamados depois de se estabelecerem em sua nova área) emigrou do norte do mundo grego. É possível que tenham sido estes imigrantes que primeiro dedicaram o local a Zeus e o chamaram de Olímpia, uma 
referência ao monte Olimpo situado entre a Tessália e a Macedônia (Berve e Gruben 1963: 14).

Deste tempo para o início do século VIII a.C., o santuário gradualmente desenvolveu-se, mas suas atividades eram limitadas às áreas de Élis e talvez a territórios vizinhos. Após 776 a.C., data tradicionalmente conservada de quando os jogos foram reorganizados, Olímpia desenvolveuse rapidamente e o número de terracotas e bronzes multiplicou-se (Yalouris 1976: 647).

No período arcaico, as atividades do santuário envolveram não apenas as cidades da Grécia continental, mas as colônias em torno do Mediterrâneo, cuja participação é evidenciada pela construção dos Tesouros datados de 676576 a.C. Entre 650 e 600 a.C. foi erigido o Templo de Hera, um edifício de ordem dórica considerado o exemplo mais antigo de templo monumental na Grécia.

De acordo com as evidências materiais encontradas no interior do santuário, sabemos que os jogos olímpicos eram celebrados em honra a Zeus desde a época em que foram reorganizados e freqüentados por diversos Estados, no final do século VIII a.C. Todavia, o culto a Zeus no local teria atingido seu auge à medida que Olímpia adquiria importância panhelênica no século V a.C.

Apesar de considerarmos que os gregos estavam 'sempre no processo de vir a ser' - e que esse processo se transformou conforme a época - a consolidação do ideal de helenidade não havia sido concluída antes do período clássico. Conforme nos explica J. Hall (2003: 219-220), foi justamente a partir do século $\mathrm{V}$ a.C., com a ameaça representada pelos persas, que a identidade helênica começou a se consolidar. Um sentimento de auto-consciência verdadeira, de helenidade, surgiu apenas depois da invasão pérsica. (Hall 2003: 220) E foi à ocasião da prática dos jogos em Olímpia que os gregos puderam praticar a helenidade.

Assim, é neste contexto que foi construído em Olímpia o templo de Zeus - relatado por Pausânias (I.X.1-4 / 4-7 / 7-9) e datado de c. 470-456 a.C. - e realizada a estátua de ouro e marfim de Zeus Olímpico de 12 metros de altura (c. 430 a.C.) descrita por Pausânias (I.XI.2-5) e por Estrabão (8.3.39).
Apesar de conhecermos a estátua de Zeus Olímpico de Fídias apenas por meio das fontes literárias, sabemos que a sua instalação no interior do templo de Zeus causou grande impacto, acrescentando algo de novo na própria religião grega. Para o arqueólogo inglês N. Gardiner (1925: 90), Fídias teria optado representar Zeus como deus da Hélade, o mais pan-helênico, de tal forma que a estátua teria transformado o culto do deus.

Nesse sentido, acreditamos que as inovações operadas no interior do santuário em relação ao culto de Zeus - motivadas pelo auge do panhelenismo no século $V$ a.C. - se estenderam também à sua representação nas artes visuais. A primeira evidência dessa inovação seguramente ocorreu com a estátua de Zeus Olímpico, cujos traços criados por Fídias, e vários deles nunca antes utilizados em uma representação de Zeus, permaneceram como exemplo a ser seguido na representação da divindade até a época romana.

Segundo nos diz Catherine Morgan (1994: 2), santuários interestaduais, como Olímpia, proporcionaram uma variedade de contatos entre diversos Estados, fomentando a difusão de instituições similares e traços culturais ao longo de uma área muito abrangente. E a busca desses traços culturais semelhantes, no caso a imagem de Zeus, a partir do documento monetário potencializa a compreensão da apropriação dessas imagens por outras póleis. Como sabemos, as moedas circulavam por lugares próximos ou longínquos, por entre várias póleis e até mesmo fora do mundo grego. As imagens, que estes pequenos objetos carregavam, muitas vezes eram copiadas por essas outras localidades. Conforme nos lembra M.B.B. Florenzano (2000: 222), os traços contidos no interior das moedas estavam sujeitos a serem vistos e rearranjados compondo novas imagens. Dessa maneira, a imagem que inicialmente representava a identidade de seu local originário, quando era readaptada por outro lugar, podia remeter ao fenômeno do panhelenismo. Portanto, a importação de uma imagem monetária pode não ter qualquer significado subjacente a não ser de assinalar a idéia de pertencimento, do grego antigo, a um mundo mais amplo.

Acreditamos que esse processo de inovação e, conseqüentemente, de transformação na 
representação de Zeus ultrapassou o espaço dos jogos olímpicos e foi apropriado por outras localidades do mundo grego. Dessa maneira, escolhemos buscar nas imagens monetárias de Zeus emitidas em Olímpia - pelas póleis de Élis e Pisa responsáveis pela organização dos jogos em épocas alternadas - as respostas acerca da influência do santuário na representação visual da mais importante divindade grega.

Portanto, a intenção desse estudo foi compreender de que modo o tipo monetário de Zeus, próprio de Olímpia, contribuiu para a consolidação de uma representação específica desta divindade no mundo grego. Para essa investigação, levantamos sistematicamente todos os tipos monetários de Olímpia cunhados nos séculos V e IV a.C. e, também, todas as imagens monetárias de Zeus emitidas no mundo grego e alguns exemplos importantes de esculturas e relevos da divindade realizados neste período. ${ }^{1} \mathrm{~A}$ partir da constituição do corpus documental, pudemos comparar as imagens monetárias de Zeus, criadas em Olímpia, com o comparandum A (tipos monetários do mundo grego) e com o comparandum B (esculturas e relevos) ao examinar as imagens 'desmontando-as' em vários elementos: forma de cabeleira, adorno de cabeça, atributos associados, posição (sentado, trovejante, etc.), de sorte a estruturar um 'repertório de unidades mínimas', analisando a 'remontagem' desses elementos nos outros suportes (Bérard e Durand 1984: 19).

O levantamento proporcionou a criação de dois catálogos numismáticos, um destinado aos tipos monetários de Zeus de Olímpia cunhados

(1) Neste estudo não consideramos os tipos monetários de Zeus Amon, culto em que Zeus foi associado a Amon, deus egípcio proveniente de Tebas cultuado como deus solar e da fertilidade. Conforme H.W. Parke (1967: 194), como um deus-carneiro, Amon, foi representado na arte egípcia com o corpo de um homem e com a cabeça do animal. Assim, nas moedas Zeus Amon aparece representado com os chifres do carneiro. Zeus Amon foi usado desde o século V a.C. primeiramente nas moedas de Cirene - era na Cirenaica que estava localizado o oráculo do deus, no oásis de Siwa - e ao longo do século IV em ilhas do Egeu. O tipo do deus foi, sobretudo, utilizado em época helenística durante período ptolomaico no Egito. em época clássica, e o outro destinado aos tipos monetários de Zeus emitidos no mundo grego (Peloponeso, Sicília, Magna Grécia, Tessália, Macedônia e Creta) no mesmo período. Por investigarmos a mudança, a alteração, e a transformação na imagem de Zeus, a documentação foi organizada nos catálogos a partir de uma ordem cronológica, portanto da datação dos exemplares encontrados. A construção de um histórico ${ }^{2}$ de cada região onde ocorreram as cunhagens e a associação aos catálogos correspondentes, mostrou o contexto de cada imagem, revelando interessantes informações sobre a especificidade da representação de Zeus nas moedas gregas.

\section{Os tipos monetários de Olímpia e os tipos monetários do mundo grego}

A partir do levantamento das fontes numismáticas - os tipos monetários de Zeus cunhados em Olímpia e aqueles emitidos no mundo grego - e da contextualização de cada exemplar monetário dentro do histórico de sua emissão, descobrimos características próprias dos tipos monetários de Zeus, quanto: A) ao início da representação de Zeus nas moedas; B) às regiões responsáveis pelas cunhagens; $\mathrm{C}$ ) às imagens monetárias que são o objeto desta pesquisa.

Primeiramente, discorreremos sobre o início das emissões monetárias de Zeus.

A primeira imagem de Zeus cunhada em uma moeda grega foi batida ao redor do ano de 490 a.C., na região do Peloponeso e por cidades que formavam a Liga Arcádia. Apesar de alguns autores terem datado esse exemplar em c. 480 a.C., a partir dessa peça situamos o início da representação de Zeus em moedas gregas na transição entre o século VI e V a.C. (Fig. 5).

Ao pensarmos na anterioridade da invenção da moeda na Ásia Menor, que ocorreu no final

(2) Por ser exaustivo, o histórico das emissões foi omitido, mas pode ser consultado em um exemplar do relatório final desta pesquisa que se encontra na biblioteca do Museu de Arqueologia e Etnologia / USP. 
do século VII a.C., e em sua subseqüente adoção pelas cidades gregas no início do século VI a.C. traçamos um histórico para o início das representações figurativas em moedas na Grécia antiga.

No mundo grego, as primeiras imagens a serem representadas em uma moeda não foram imagens de deuses ou deusas, ninfas ou heróis, mas sim imagens de animais. A escolha de divindades como símbolo da pólis ocorreu em um período um pouco posterior. De acordo com um breve levantamento no catálogo do livro Archaic and Classical Greek Coins (1976) - escrito pelo numismata e arqueólogo inglês Colin Kraay - encontramos na Sicília uma das imagens mais antigas. Trata-se da figura da cabeça de Dioniso, emitida pela pólis de Naxos em c. 530 a.C. Sabemos que a datação dessas moedas foi, em muitos casos, feita de forma aproximada e sem um contexto histórico bem determinado. No entanto, outras imagens monetárias de divindades são conhecidas de c. 525 a.C, como a figura de Apolo cunhada em Caulônia e a imagem de Poseidon emitida em Posidônia, na Magna Grécia. É interessante notar que as mais antigas representações monetárias de deuses firmaram-se nas áreas coloniais, cujas emissões são das mais antigas do mundo grego.

Diante do contexto das mais antigas representações de divindades em moedas gregas, percebemos que a imagem de Zeus foi escolhida como tipo monetário em um período posterior, aproximadamente meio século depois. Decerto, o contraste temporal entre a adoção das imagens de outros deuses e a de Zeus, em um período de transição, pode indicar características específicas do culto de Zeus até então desconhecidas ou que passaram despercebidas, pois não foram estudadas à luz do contexto de culto da divindade.

É importante apontar que os primeiros templos dedicados a Zeus datam também desse período de transição entre os anos finais da época arcaica e os anos iniciais da época clássica. Esses templos são justamente aqueles dedicados a Zeus Olímpico, como é o caso do templo em Atenas construído em c. 510 a.C. Os Olimpiéia - como são chamados os templos de Zeus Olímpico - são conhecidos como os primeiros templos monumentais e representam o auge do estilo dórico.
Materialmente documentado através dos templos e das moedas, encontramos um contexto histórico definido para o desenvolvimento do culto de Zeus. A primeira emissão de uma imagem monetária de Zeus em c. 490 a.C. corresponde aos templos mais antigos da divindade no mundo grego. Além disso, existe também uma correspondência entre os locais dessas inovações. O Peloponeso e a Sicília foram as únicas regiões a cunharem tipos monetários de Zeus no século $\mathrm{V}$ a.C., e possuíam estreitas relações desde o período arcaico, como veremos mais adiante.

Assim, na associação entre o momento da emissão da primeira imagem de Zeus e dos primeiros templos construídos em honra a ele, notamos que na transição entre o século VI e V a.C. o culto a Zeus adquiriu visibilidade nestas duas categorias de documentos.

As hipóteses levantadas acerca de uma transformação no culto de Zeus no período apontado serão estudadas em uma pesquisa futura. Por enquanto, a exposição dessas idéias é útil para mostrar que por trás da influência de Olímpia, na representação de Zeus no mundo grego, podem estar questões mais amplas.

Apesar de a primeira imagem monetária de Zeus ser datada do limiar do século VI a.C. (490 a.C.), consideramos que o século $\mathrm{V}$ a.C. foi o período em que ocorreram as primeiras moedas com imagens da divindade. O exemplar de 490 a.C. cunhado pela Liga Arcádia, será considerado apenas como uma evidência de que as imagens de Zeus utilizadas nas moedas começaram a ocorrer em um período de transição.

O levantamento dos tipos monetários de Zeus, emitidos no mundo grego em época clássica, revelou que o século V a.C. foi o primeiro momento em que houve o interesse pela representação da imagem de Zeus em moedas, como atestam a quantidade de emissões com a imagem do deus no período. É interessante notar que existiu um vazio entre o período arcaico e a primeira data que temos para um tipo monetário de Zeus (490 a.C.). Por isso, a única explicação encontrada para esse fenômeno remete-nos ao desenvolvimento da pan-helenidade de Zeus que vinha ocorrendo desde o final do século VI e atingiu o ápice no século V a.C. Nesse 
Tabela I

\begin{tabular}{|c|c|c|c|}
\hline 1) Cabeça & $\begin{array}{l}\text { a) cabelo curto ou } \\
\text { longo }\end{array}$ & $\begin{array}{l}\text { b) barba curta ou } \\
\text { longa }\end{array}$ & $\begin{array}{l}\text { c) coroa de folhas de } \\
\text { oliveira, de louro, ou } \\
\text { de carvalho }\end{array}$ \\
\hline 2) Sentado & a) trono ou rocha & $\begin{array}{l}\text { b) posição do cetro } \\
\text { (braço esquerdo ou } \\
\text { direito) }\end{array}$ & $\begin{array}{l}\text { c) posição da águia } \\
\text { (braço esquerdo ou } \\
\text { direito) }\end{array}$ \\
\hline 3) Em pé correndo & $\begin{array}{l}\text { a) posição do raio } \\
\text { (braço esquerdo ou } \\
\text { direito) }\end{array}$ & $\begin{array}{l}\text { b) posição da águia } \\
\text { (braço esquerdo ou } \\
\text { direito) }\end{array}$ & \\
\hline
\end{tabular}

sentido, acreditamos que o auge do ideal de helenidade no século V a.C. teria impulsionado a representação de Zeus em moedas gregas.

O levantamento sistemático dos tipos monetários de Zeus, cunhados em época clássica, configurou um mapa das mais variadas regiões do mundo grego, que foram responsáveis pelas emissões. Como observamos através do histórico realizado sobre esses exemplares, o Peloponeso, a Sicília, a Magna Grécia, a Tessália, a Macedônia e a ilha de Creta, destacaram-se como os locais que escolheram Zeus como a imagem representada em suas moedas.

Dentre essas regiões, destacamos o Peloponeso e a Sicília como os únicos locais a emitirem tipos monetários de Zeus no século V a.C. Acreditamos que a coincidência entre as duas regiões, como os locais responsáveis pelas emissões mais antigas da divindade, se deva às estreitas relações mantidas por ambas as regiões. Sabemos que de várias áreas do Peloponeso saíram os fundadores das cidades gregas na Sicília. Mas sabemos também que desde o início da colonização da Sicília, a região manteve sua relação com o Peloponeso devido à participação dos atletas das cidades siciliotas nas Olimpíadas. Por isso, Olímpia é considerada pelos estudiosos como o mais notável centro dórico e ocidental do mundo grego (Marinatos e Hägg 1993: 230).

No século IV a.C. ocorreu um aumento de regiões a utilizarem a imagem de Zeus nas moedas. As póleis do Peloponeso e da Sicília continuaram a emitir imagens monetárias do deus, mas a Magna Grécia, a Tessália, a Macedônia e Creta iniciaram emissões monetárias com o tipo do deus neste período.
Assim, para traçarmos alguma influência do santuário de Olímpia no aumento da representação de Zeus nestas regiões, durante o século IV a.C., recorremos à fonte textual Catálogo dos Vencedores Olimpicos da Antiguidade. ${ }^{3}$ Trata-se do registro dos vencedores nas Olimpíadas desde 776 a.C. e que traz a origem dos atletas vitoriosos. Por isso, essa fonte nos permitiu encontrar a ocorrência da participação dessas regiões nos jogos olímpicos durante o período clássico. Nesse sentido, ao contrastarmos os dados referentes aos tipos monetários de Zeus com o registro dos vencedores nos jogos notamos certas correspondências entre moeda e região.

Mas para correlacionarmos as informações referentes às moedas e às regiões devemos, primeiramente, apresentar os critérios para nossa busca, ou seja, o padrão de representação de Zeus nas moedas.

De um modo geral, podemos encontrar nas moedas gregas três formas de representação de Zeus: 1) Cabeça; 2) Sentado; 3) Em pé correndo. Além dessas classificações existem outros elementos menores que acompanham esses tipos de imagem (Tabela I).

(3) Foi compilado pela primeira vez por volta de 400 a.C. pelo sofista Hípias de Élis, que, para as Olimpiadas mais antigas, provavelmente se baseou nos antigos registros de Olímpia, tradições orais e reminiscências ainda existentes no local. $\mathrm{O}$ trabalho de Hípias foi revisto e continuado no século IV a.C. por Aristóteles e posteriormente por Flégon de Trális e outros. Ele foi transformado em um tipo de crônica olímpica e já no século III a.C. constituía a base do antigo sistema cronológico. (Yalouris 2004: 314) Em nosso estudo, utilizamos a versão publicada em Os Jogos Olimpicos na Grécia Antiga (2004), que foi organizada por Nicolau Yalouris. 
A relação de um repertório de unidades minimas, evidenciados na tabela acima, permite a visualização de possíveis alterações nas imagens e, também, a repetição de determinados elementos em um e em outro tipo monetário. Para utilizarmos esse critério, em primeiro lugar, devemos estabelecer o padrão de representação de Zeus nas moedas fabricadas em Olimpia (Tabela II).

Após apresentarmos os padrões dos tipos monetários de Olímpia e os padrões dos tipos monetários de Zeus encontrados no mundo grego, poderemos relacioná-los às imagens de ambos os locais. Mas para isso analisaremos cada tipo de imagem a partir dos locais onde foram utilizados.

O primeiro padrão de imagem de Zeus a ser utilizado em uma moeda foi Zeus em pé, em posição de corrida (pernas abertas), atirando o raio com a mão direita e sobre o braço esquerdo, a águia. A análise do levantamento dos tipos monetários do mundo grego em associação aos tipos cunhados em Olímpia revelou que esse padrão de imagem de Zeus é típico do século $\mathrm{V}$ a.C. e foi utilizado unicamente no Peloponeso e na Sicília.

No Peloponeso, a imagem de Zeus em pé e correndo foi usada por Élis para o reverso das moedas de Olímpia, cujas peças correspondem à primeira emissão monetária com imagem de Zeus emitida no santuário, sendo datadas de 470 a.C., a primeira data de que dispomos para um tipo monetário de Zeus cunhado em Olímpia (Fig. 1).

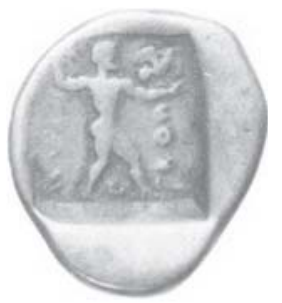

Fig. 1. ANS 1985: Fig. 1858.

Mas também encontramos essa imagem nos reversos de tipos monetários cunhados entre 452 e 432 a.C. (Fig. 2).

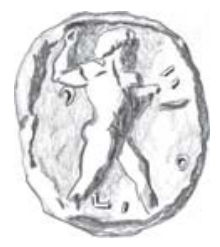

Fig. 2. Seltman 1921: Fig. 73. Desenho: Cássia Bars.

Essas imagens de Zeus foram interpretadas como uma referência às estatuetas de Zeus dito trovejante - utilizadas no culto do deus durante o período arcaico e início do período clássico que foram encontradas no local (Fig. 38).

$\mathrm{Na}$ Sicília, a imagem foi encontrada em uma moeda de Zancle datada de c. 460 a.C. O

Tabela II

Tipo monetário

I. Zeus em pé correndo e atirando o raio com a mão direita e sobre o braço esquerdo, a águia.

II. Zeus sentado no trono segurando um cetro com a mão esquerda e a águia voando próximo à mão direita.

III. Zeus sentado numa rocha e sobre seu braço esquerdo o cetro e sobre o direito, a águia.

IV. Cabeça de Zeus com cabelos curtos e barba curta (coroa de folhas de oliveira).

V. Cabeça de Zeus com cabelos longos e barba longa (coroa de folhas de oliveira).
Padrão pertencente ao século

Va.C.

Va.C.

Va.C.

V e IV a.C.

IV a.C. 
anverso da peça mostra a figura de Zeus em pé correndo e atirando um raio com a mão direita (Fig. 3). Não encontramos no campo da moeda a imagem da águia que costuma acompanhar esse padrão de representação.

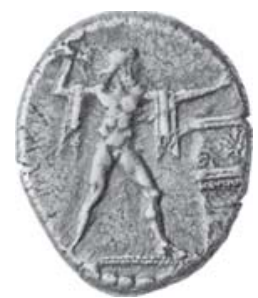

Fig. 3. Kraay 1976: Fig. 774.

O outro tipo monetário que encontramos foi cunhado pela pólis de Messênia, no Peloponeso, mas durante o século IV a.C. No reverso encontramos o padrão típico dessa representação: Zeus aparece em pé e correndo, segurando um raio com a mão direita e, sobre o braço esquerdo, a águia (Fig. 4). Essa moeda é datada de 369 a.C. e foi cunhada após a fundação da polis de Messênia por Epaminondas. Os estudiosos defendem que a imagem de Zeus nesta moeda é uma cópia da estátua de Zeus Ithomates, cultuada no monte Ithome na Messênia, e foi obra do escultor Ageladas de Argos. Infelizmente a estátua não chegou aos dias atuais, mas através da descrição de Pausânias (4.33.2) sabemos que pertenceu ao período arcaico e que foi feita no século VI a.C., considerado o período de atividade do escultor (Gardner, BMC: XLIII; Kraay 1976: 102; Shipley 2005: 564).

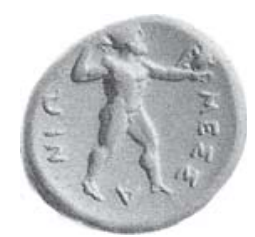

Fig. 4. Kraay 1976: Fig. 322.

No tocante a essa representação, não conseguimos traçar alguma influência de Olímpia na representação desse padrão. Apenas podemos inferir que as imagens desse tipo cunhadas no Peloponeso, em Olímpia (século V a.C.) e na Messênia (século IV a.C), possuem algumas semelhanças percebidas nos elementos menores que compõem a imagem. Mas acreditamos que isso se deva ao fato de que ambos os desenhos remetem às estátuas de Zeus trovejante, cujo padrão de representação era o mesmo desde o período arcaico. Como veremos mais adiante, essas estátuas correspondem ao tipo de representação de Zeus na escultura que foi preponderante até o início do período clássico. Acreditamos também que a ocorrência desse tipo de representação nas moedas da primeira metade do século $V$ a.C. possa ser uma reminiscência dessas esculturas.

Acerca de Zancle, não encontramos nenhuma vitória desta pólis nos jogos olímpicos em época clássica e em nenhuma olimpíada anterior a esse período. Apesar de esse dado não excluir a possibilidade da participação dos zancliotas nos jogos nessa época. Essa imagem de Zeus foi escolhida para as emissões de 460 a.C. em comemoração ao fim da tirania em Zancle (Fischer-Hansen, Nielsen e Ampolo 2005: 235). Observando atentamente os elementos menores presentes na imagem de Zeus, percebemos que diferem dos tipos do Peloponeso, pois não encontramos o desenho da águia e Zeus usa um manto. Nesse sentido, não podemos tecer considerações que mostrem na imagem dessa moeda traços no desenho semelhantes aos traços da imagem de Olímpia.

O próximo padrão de representação de Zeus encontrado em moedas gregas foi aquele em que o deus aparece sentado. Esse tipo foi utilizado, exclusivamente, em emissões do Peloponeso, da Sicília, da Macedônia e de Creta.

As mais antigas representações desse padrão são datadas de c. 490 a.C. e foram cunhadas na cidade de Cleitor para a Liga Arcádia, no Peloponeso. Esses exemplares correspondem aos tipos monetários de Zeus mais antigos e são importantes para compreendermos o culto de Zeus entre o século VI e V a.C. Esse padrão foi utilizado no anverso das moedas e Zeus foi desenhado sentado em um trono, ora à esquerda ou ora à direita, segurando um cetro com a mão esquerda e uma águia com a mão direita, vestindo um himátion (Fig. 5).

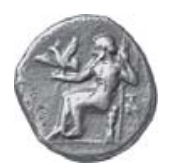

Fig. 5. Williams 1965: Fig. 3. 
Em uma outra emissão, no anverso, Zeus está sentado no trono à direita com um himátion, segurando um cetro com sua mão esquerda, mas segurando um raio alado com sua mão direita (Fig. 6). Esse exemplar é datado entre os anos de 477 e 468 a.C.

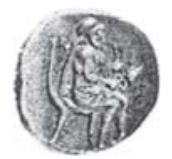

Fig. 6. Williams 1965: Fig. 126.

Em Olímpia esse padrão ocorreu em moedas de duas emissões diferentes datadas entre 452 e 432 a.C. No anverso da primeira moeda, Zeus é representado no trono à esquerda, segurando um cetro com a mão esquerda e a águia voando próximo ao braço direito (Fig. 7).

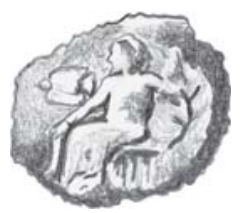

Fig. 7. Seltman 1921: Fig. 99. Desenho: Cássia Bars.

Esse tipo monetário é considerado muito semelhante àqueles cunhados pela Liga Arcádia. Mas encontramos também em Olímpia uma variação desse padrão de imagem. No anverso de uma moeda datada ao redor desses mesmos anos, Zeus foi representado sentado em uma rocha e não em um trono como antes. Ele veste um himátion, e o cetro e a águia aparecem ao lado direito do deus (Fig. 8).

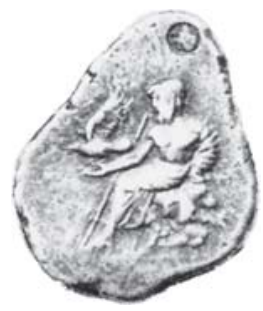

Fig. 8. Sear 1978: Fig. 2866.

As semelhanças presentes nos desenhos das moedas da Liga Arcádia e das moedas cunhadas por Élis em Olímpia - sobretudo Figs. 6 e 7 - sugerem uma influência de um local sobre o outro. Como nos apoiamos nas datações dos exemplares percebemos que o tipo cunhado pela Liga Arcádia é mais antigo do que o tipo cunhado em Olímpia. Assim, a imagem de Zeus da moeda de Olímpia é posterior à imagem da Liga Arcádia. Nesse sentido, o tipo de Zeus sentado no trono cunhado no santuário pan-helênico pode ser uma cópia da representação do deus nessas primeiras emissões da Liga Arcádia. Contudo, essa constatação não exclui a possibilidade de os tipos batidos em Olímpia terem, a posteriori, difundido a idéia desse padrão de representação às outras áreas do mundo grego.

$\mathrm{Na}$ Sicília esse tipo de representação de Zeus ocorre com variações nos elementos menores que costumam compor o desenho. Em Aetna, no reverso de moedas datadas de 460 a.C. Zeus é retratado à direita sentado em um trono, segurando um raio ou um cetro com a mão direita e um raio alado com a mão esquerda. A águia aparece representada sobre uma árvore (Fig. 9) e sobre um cetro (Fig. 10).

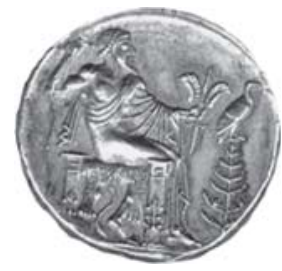

Fig. 9. Kraay 1976: Fig. 838

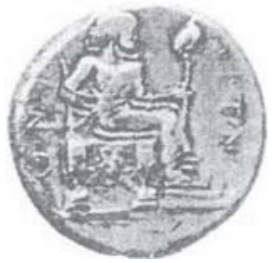

Fig.10. Kraay 1976: Fig. 837.
As variações no desenho desse padrão de representação de Zeus, ocorrida em Aetna, são relacionadas à adaptação local do tipo, como vimos no histórico sobre essa emissão. No anverso da moeda de Galária, datada do mesmo ano do tipo de Aetna, c. 460 a.C., Zeus é mostrado sentado em um trono à esquerda, segurando um cetro com a mão esquerda e sobre ele a águia (Fig. 11).

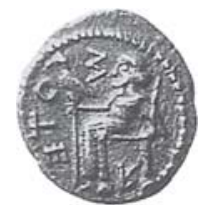

Fig. 11. Manganaro 2003: Fig. 2. 
Esse padrão de representação ocorre novamente apenas em moedas no século IV a.C. em Creta e na Macedônia e em um caso isolado no Peloponeso.

A Liga Acaia em c. 365 a.C. emite moedas cujo reverso é a imagem de Zeus sentado no trono segurando um cetro com a mão esquerda. Abaixo da mão esquerda aparece a figura de um elmo (Fig. 12).

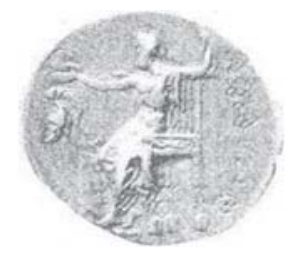

Fig.12. Sear 1978: Fig. 2968.

Em Creta, encontramos esse tipo no anverso de moedas de Cnossos datadas de c. 350 a.C. Zeus aparece sentado num trono à esquerda segurando um cetro com a mão esquerda e uma Nike com a mão direita (Fig. 13).

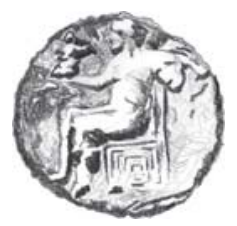

Fig. 13. BMC, Crete and Aegean Islands: Pl. V, 14. Desenho: Cássia Bars.

Deste mesmo ano temos a moeda de Praisos, em cujo anverso Zeus aparece sentado de frente segurando um cetro com a mão esquerda e uma águia com a direita (Fig. 14).

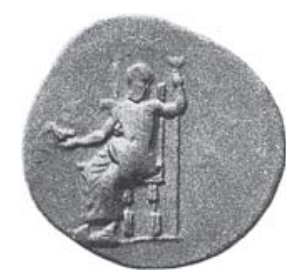

Fig. 14. Sear 1978: Fig. 3363.

Em c. 330 a.C. a cidade cretense de Olonte bateu uma moeda, em cujo reverso está a figura de
Zeus sentado no trono, segurando um cetro com a mão esquerda e a águia com a direita (Fig. 15).

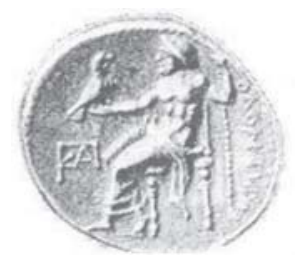

Fig. 15. Sear 1978: Fig. 3340.

Na Macedônia o tipo de Zeus sentado foi cunhado em c. 331 a.C. e faz parte das emissões reais de Alexandre, o Grande. No reverso deste exemplar, Zeus é retratado sentado no trono, segurando um cetro com a mão direita e uma águia com a mão direita; veste um himátion (Fig. 16).

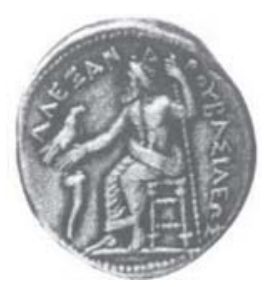

Fig. 16. ANS 1985: Fig. 1124.

O estudioso responsável pelo maior estudo sobre Zeus, A. R. Cook (1921: 760-762), acredita que o tipo de Zeus sentado no trono retratado nas moedas de Alexandre não foi inspirado no tipo de Olímpia, mas no tipo da Liga Arcádia.

A partir da análise iconográfica centrada no padrão e nos elementos menores ou unidades mínimas, concluímos que o tipo monetário de Zeus sentado no trono é uma inovação e, por conseguinte, uma contribuição da Liga Arcádia no Peloponeso, realizada no século V a.C. A imagem de Zeus sentado em um trono cunhada em Olímpia é muito parecida com aquelas da Liga Arcádia e por isso não a consideramos como uma imagem criada no santuário. Mas o tipo de Zeus sentado em uma rocha é próprio de Olímpia e por isso considerada por nós uma inovação local.

Todavia, as imagens encontradas em Creta correspondem ao padrão de representação da 
Liga Arcádia, pois nessas moedas Zeus é representado sentado no trono e segura com a mão esquerda um cetro e com a direita a águia, apesar de essas imagens não serem parecidas com o desenho utilizado pelas moedas arcádias, como notamos entre essas e as moedas de Olímpia.

O último padrão para a representação de Zeus, a cabeça, proporcionou conclusões interessantes.

O levantamento dos tipos monetários de Zeus cunhados em Olímpia e dos tipos cunhados no mundo grego mostrou-nos que as primeiras cabeças de Zeus foram representadas nas moedas de Élis, em Olímpia, e nas moedas da Liga Arcádia na segunda metade do século $\mathrm{V}$ a.C. E assim, esses são os únicos dois casos que conhecemos desse padrão de representação no século $\mathrm{V}$ a.C. caracterizando esses locais como responsáveis pela representação das mais antigas cabeças do deus em moedas gregas.

A datação das moedas da Liga Arcádia, c. 428-418 a.C., em relação à datação da cabeça de Zeus emitida em Olímpia, c. 416 a.C., leva-nos a concluir que o tipo arcádio é mais antigo que o tipo de Olímpia e, por isso, consideramos a imagem cunhada no anverso por Mantinéia (Fig. 17) na Arcádia a representação mais antiga de que dispomos da cabeça de Zeus. Por outro lado, se considerarmos a margem de erros que podem ocorrer no estabelecimento da cronologia das séries monetárias e os poucos anos que separam a cunhagem dos dois locais, o uso do tipo da cabeça pode ter ocorrido simultaneamente tanto em Olímpia como em Mantinéia.

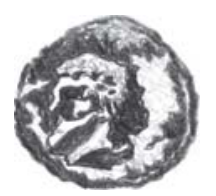

Fig. 17. Williams 1965: Fig. 319. Desenho: Cássia Bars.

Novamente, notamos que tanto Élis como as cidades que batiam moedas para a Liga Arcádia foram responsáveis por inovações na imagética de Zeus das moedas gregas. Acreditamos que isso se deva ao fato de que ambos os locais foram importantes centros de culto a Zeus no Peloponeso, o que teria motivado padrões novos de representação da divindade, além de uma troca de imagens entre os locais, como vimos no tocante ao tipo de Zeus sentado no trono.

O desenho da cabeça de Zeus no anverso à direita com coroa de folhas de oliveira, cabelos curtos e barba curta (Fig. 18), cunhada em Olímpia ao redor de 416 a.C., é interpretado por Charles Seltman como uma imagem muito próxima às esculturas da métopa do templo de Zeus em Olímpia. A partir desta moeda, o pesquisador concluiu que houve uma influência do 'mestre de Olímpia' nos gravadores de cunho, que fizeram os desenhos das moedas locais (Seltman 1948: 71).

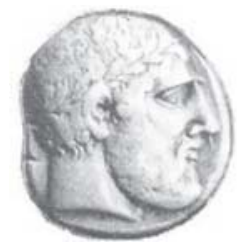

Fig. 18. Sear 1978: Fig. 2871.

É interessante notar que a representação da cabeça só volta a ocorrer em moedas no século IV a.C. em cidades da Sicília, da Magna Grécia, da Tessália, na Macedônia e em Creta.

De acordo com as datações dos exemplares, a primeira imagem monetária da cabeça de Zeus, cunhada no século IV a.C, e que não pertence às emissões de Élis para Olímpia, foi emitida por Megalópolis no Peloponeso para a Liga Arcádia à época da fundação desta pólis. No anverso dessas moedas, a cabeça de Zeus com coroa de folhas de oliveira é representada com cabelos longos bem densos e barba longa (Fig. 19).

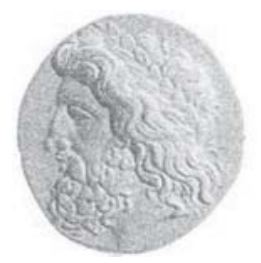

Fig. 19. Kraay 1976: Fig. 319.

A próxima imagem mais antiga fez parte das emissões de Felipe II da Macedônia. A 
cabeça de Zeus no anverso à direita com cabelos longos e barba é datada de 356 a.C. (Fig. 20).

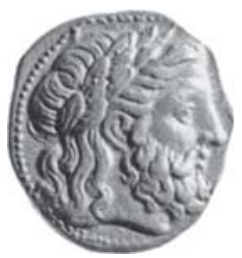

Fig. 20. Kraay: Fig. 512.

Como dissemos anteriormente, essa imagem é uma referência a Zeus de Olímpia, pois complementa a comemoração de Felipe II pela primeira vitória na corrida a cavalo nos jogos olímpicos de 356 a.C. Mas, assim como a cabeça de Apolo no anverso das moedas de ouro, a representação de Zeus de Olímpia foi deliberadamente escolhida como uma expressão da propaganda pan-helênica de Felipe (Kraay 1976: 147). Nesse sentido, este caso parece ser o único conhecido por nós em que houve uma influência das imagens de Olímpia sobre outra imagem de Zeus no mundo grego, o qual é atestado a partir de eventos históricos, no caso, as vitórias de Felipe nos jogos olímpico e a política de expansão do império macedônio.

Durante o século IV a.C. o santuário de Olímpia apenas emitiu cabeças de Zeus com coroa de folhas de oliveira, cabelos curtos e barbas curtas até a primeira metade do século e, na segunda metade do século, emitiu cabeças de Zeus com coroa de folhas de oliveira, cabelos longos e barbas longas.

Para diferenciarmos a coroa de folhas de oliveira da coroa com folhas de louro utilizamos os desenhos da enciclopédia Koehler's MedicinalPlants (1887), ${ }^{4}$ que segue ao lado:

(4) É um guia alemão raro sobre a farmacopéia européia publicado em três volumes, escrito por Franz Eugen Köhler e editado por Gustav Pabst. As aquarelas das folhas de oliveira e das folhas de louro foram obtidas no site Wikipedia: (http://en.wikipedia.org/wiki/Olive_tree) e (http://en.wikipedia.org/wiki/Laurus_nobilis).

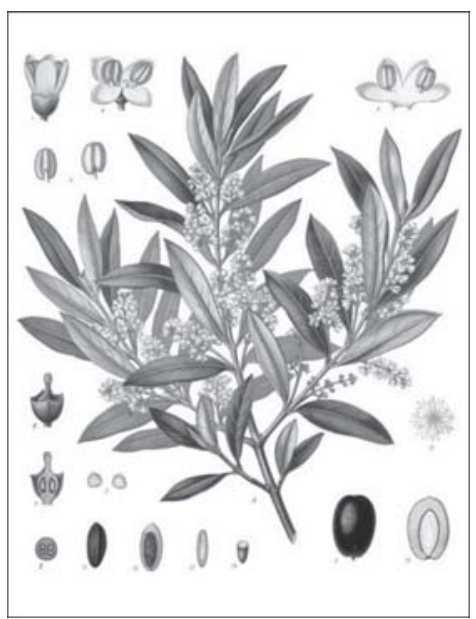

Folhas de oliveira (Olea europaea)

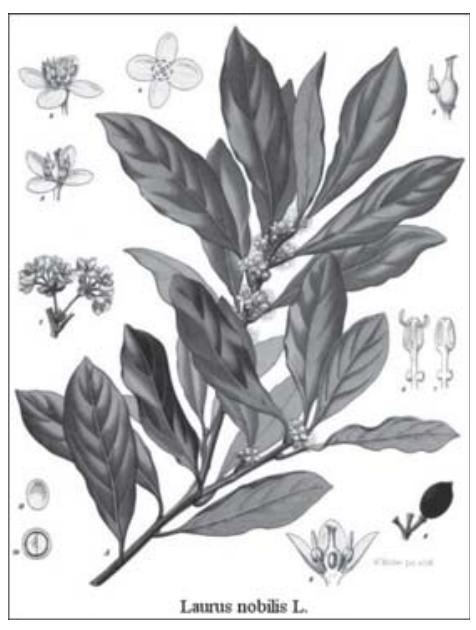

Folhas de louro (Laurus nobilis)

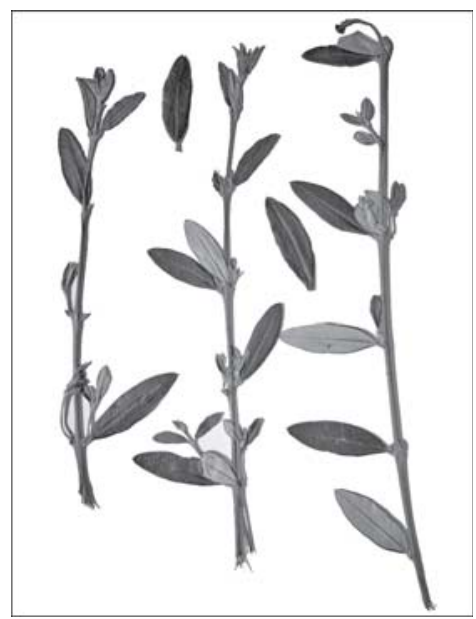

Folhas de oliveira de Olímpia 
Como podemos perceber, as folhas da oliveira (Olea europaea) são mais finas e pontudas em relação às folhas do louro (Laurus nobilis) que são mais volumosas. Esse, portanto, foi o critério de diferenciação na classificação das coroas presentes nos desenhos da cabeça de Zeus nas moedas. Devemos dizer, primeiramente, que o desgaste da imagem monetária e a precariedade da foto tirada do tipo dificultaram em alguns casos a classificação das folhas da coroa.

Assim, a partir deste parâmetro conseguimos identificar claramente a presença da coroa de folhas de oliveira nas cabeças de Zeus cunhadas em Olímpia. Em todas as imagens das cabeças de Zeus com cabelo curto ou longo, emitidas no santuário, notamos a existência da coroa de folhas de oliveira, que é inexistente na imagem da cabeça de Zeus cunhada pela Liga Arcádia no século V a.C. Assim, podemos afirmar que a coroa de folhas de oliveira pode ser uma inovação do santuário de Olímpia acerca da imagética de Zeus nas moedas. Dentre os tipos monetários de Olímpia, destacamos o anverso do exemplar datado de c. 360 a.C., considerado por esta pesquisa como a imagem mais definida das folhas de oliveira (Fig. 21). Neste caso, acreditamos que a proximidade do desenho das folhas, vistas na moeda, com as folhas naturais da oliveira mostra a intenção do artista responsável pela gravação do cunho em diferenciar a folha de oliveira da folha de outra planta. Este tipo monetário de Zeus também nos leva a pensar que de fato existem diferenças na representação de coroas para a imagem da cabeça de Zeus em moedas, nos forçando a rever a classificação "laureada" (em inglês, laureate) utilizada nos catálogos numismá-

(5) No Novo Dicionário Aurélio, encontramos a palavra laureado (Do lat. laureatu) Adj. 1. Que recebeu láurea ou laurel. 2. Festejado; aplaudido; louvado. Laurear (Do lat. laureare) V. t.d. 1. Coroar ou cingir de louros (Holanda 1975: 823 e 824). ticos para a presença da coroa junto à cabeça do deus.

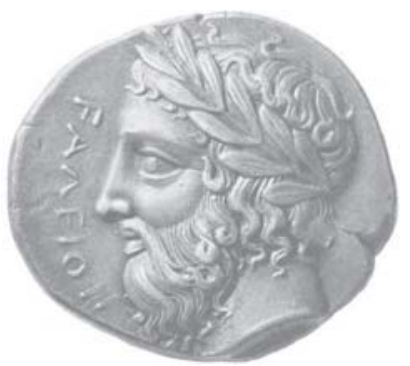

Fig. 21. Kraay: Fig. 336.

Esse elemento pode ser visto em todas as representações de cabeças de Zeus na Sicília, Magna Grécia e na ilha de Creta. Na Sicília, ao redor de 345 a.C., as póleis de Siracusa (Fig. 22), Agyrion (Fig. 23), Agrigento (Fig. 24) e Érice emitiram cabeças de Zeus com coroa de folhas de oliveira, cabelos longos ou curtos e barba longa ou curta.

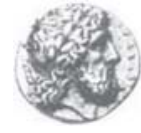

Fig. 22. SNGuk (III): Fig. 996.

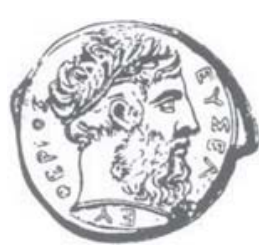

Fig. 23.

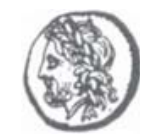

Fig. 24. BMC, Sicily: p. 13-14.
Na Magna Grécia, Zeus foi representado usando coroa de folhas de oliveira nas moedas de Locri com cabelos curtos e barba curta (Fig. 25) e posteriormente com cabelos longos e barba longa (Fig. 26).
Fig. 25. Kraay 1976: Fig. 719.

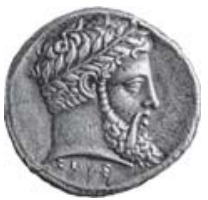

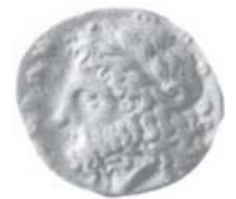

Fig. 26. SNGCop (I): Fig. 1858.
Nas moedas de Metaponto, vemos a cabeça de Zeus com cabelos longos e barba 
longa (Fig. 27). Em Metaponto, também, foi cunhada uma moeda com a cabeça de Zeus no anverso, com cabelos longos e barba longa (Fig. 28), mas a coroa é de folhas de carvalho, uma referência à origem epirota de Alexandre Molosso; as folhas de carvalho remetem ao santuário de Zeus em Dodona, apesar de o tipo de representação ser próprio das moedas de Olímpia.

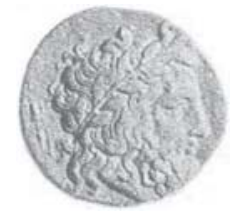

Fig. 27.

SNGuk (III):

Fig. 410.

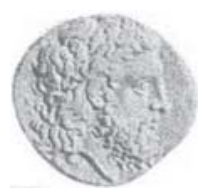

Fig. 28. Kraay 1976: Fig. 686.
$\mathrm{Na}$ Tessália não encontramos a representação da cabeça de Zeus com coroa de folhas de oliveira, mas com coroa de folhas de louro. Mas é a região que se destaca pela quantidade de moedas com a imagem da cabeça de Zeus com cabelos longos e barba longa. Encontramos esse tipo de representação no anverso de moedas datadas de 350 a.C. nas cidades de Hypata, Ekkara e Melitaia (Figs. 29, 30, 31).

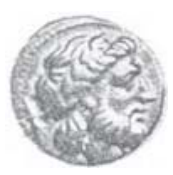

Fig. 29. Sear 1978: Fig. 2096.

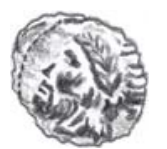

Fig. 30. Sear 1978: Fig. 2079. Desenho: Cássia Bars.

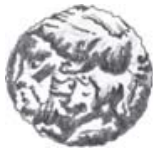

Fig. 31. Sear 1978: Fig. 2148. Desenho: Cássia Bars.

De 344 a.C. são datadas as cabeças cunhadas no anverso de moedas em Kierion (Figs. 32 e 33) e Gyrton (Fig. 34).

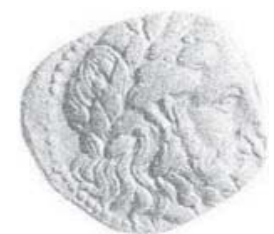

Fig. 32.

Kraay 1976: Fig. 398.

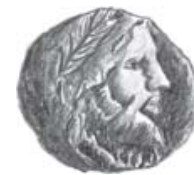

Fig. 34.

SNGCop (III): Fig. 59.

Desenho: Cássia Bars.

É interessante notar que até o final do século $\mathrm{V}$ a.C. atletas da Tessália obtiveram vitórias nos jogos olímpicos, o que ocorreu por todo o século IV a.C. Tal informação se estende também à participação de outras localidades do norte do mundo grego. Essa participação dos tessálios nas olimpíadas vista através das vitórias nos jogos pode ter ocorrido à medida que o povo dessa região foi considerado como grego. Assim, podemos supor que as representações da cabeça de Zeus nessas moedas, com cabelo longo e barba longa, cunhadas na Tessália podem ter sido impulsionadas pela participação dessa região nos jogos olímpicos, pois se observarmos as moedas cunhadas em Olímpia neste século veremos que existe uma correspondência entre a predominância da emissão de moedas com a cabeça de Zeus no santuário e as cabeças de Zeus nas moedas da Tessália. Essas moedas possuem as mesmas características dos tipos de Olímpia no tocante à utilização dos cabelos compridos e barbas densas. Finalmente, em Creta encontramos duas cidades que cunharam esse padrão de representação. Em Hierapytna (Fig. 35) e em Polyrhenion (Fig. 36) foram cunhadas, no anverso, cabeças de Zeus com cabelos longos e barba longa ao redor de 330 e 325 a.C.

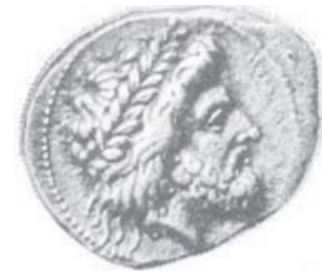

Fig. 35.

Sear 1978: Fig. 3350.

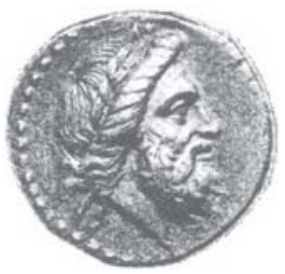

Fig. 36.

Sear 1978: Fig. 3304. 
Colin Kraay (1976: 107) atribuiu essas imagens aos tipos cunhados de Olímpia, mas se observarmos os tipos das outras regiões, os quais possuem maior proximidade com as imagens do santuário, veremos que essas moedas cretenses possuem originalidade própria.

Em suma, a representação da cabeça de Zeus (com coroa de folhas de oliveira e com coroa de folhas de louro) foi uma invenção do século $\mathrm{V}$ a.C., mas que foi adotada no século IV a.C. como modelo para a representação de Zeus nas moedas gregas, se consolidando como padrão de representação no período helenístico.

\section{A representação de Zeus nas esculturas e relevos: apresentação da documentação}

Para discorrermos acerca das esculturas e relevos de Zeus feitos em época clássica e, por conseguinte, compararmos essas representações com as imagens monetárias de Zeus em Olímpia, devemos primeiramente situar a nova documentação (comparandum B) no contexto das representações de Zeus nesse tipo de suporte imagético, representações que remontam ao início do período arcaico e foram encontradas em diversas regiões do mundo grego.

Para tanto, utilizaremos as informações obtidas a partir do Lexicon Iconographicum Mythologiae Classicae (LIMC). Como o nome indica, trata-se de um léxico que contém um histórico sobre as representações de divindades, heróis e outros personagens da mitologia grega e romana.

Conforme M. Tiverios (1997: 315), os primeiros registros, que mencionam o nome de Zeus, datam do segundo milênio a.C. e foram encontrados nas tábuas escritas em Linear B nas cidades cretenses de Pilos, Cnossos e Chaniá. Desse período também parecem datar as primeiras representações do deus em monumentos da civilização creto-micênica. Contudo, essas identificações são meramente especulativas.
Para a maioria dos especialistas as representações mais antigas de Zeus, que são confirmadas, são datadas entre a última década do século VIII a.C. e os primeiros anos do século VII a.C. Nessas representações, o deus é retratado imberbe ou com barba, segurando um raio e uma águia ou dois raios, ou ainda um raio ou um cetro. Tiverios cita um relevo ${ }^{6}$ de um pithos datado do século VII a.C., no qual Zeus aparece sentado no trono, como a representação mais antiga desse tipo.

Diferentes tipos de representação do deus se desenvolveram em diferentes regiões, evidentemente relacionados à especificidade do culto nestes locais. Entretanto, certos padrões de representação de Zeus permaneceram como uma convenção artística e são vistos em todas as regiões do mundo grego.

Os atributos que compõem a sua representação, uma criação do final do século VIII e do início do século VII a.C., são reproduzidos no século VI a.C. e permanecem representados com a divindade até o final da Antiguidade. Ainda neste século, o deus é representado com cabelo curto, barba e bigode, embora em alguns casos encontremos figuras imberbes do deus (Tiverios 1997: 322).

A partir do século VI a.C. (o último século do período arcaico), a variedade iconográfica na representação de Zeus - uma característica do século VII a.C. - passou a diminuir significantemente. Tipos específicos de representação do deus começaram a surgir e vários dos quais tiveram uma longa duração, tais como o tipo de Zeus em pé (Keráunios) e o tipo de Zeus sentado. Encontrada em Posidônia, em centenas de fragmentos esparsos entre o templo de Poseidon e a extremidade setentrional do santuário, a estátua de terracota de Zeus no trono (Fig.37), datada de 530-520 a.C., é um bom exemplo deste padrão de representação no período.

(6) Nascimento de Atena. Relevo de um pithos. Data: segundo quartel do século VII a.C. Localidade: Londres, Museu Britânico. Proveniência: Tunos. Bibliografia: LIMC (VIII): 317. 


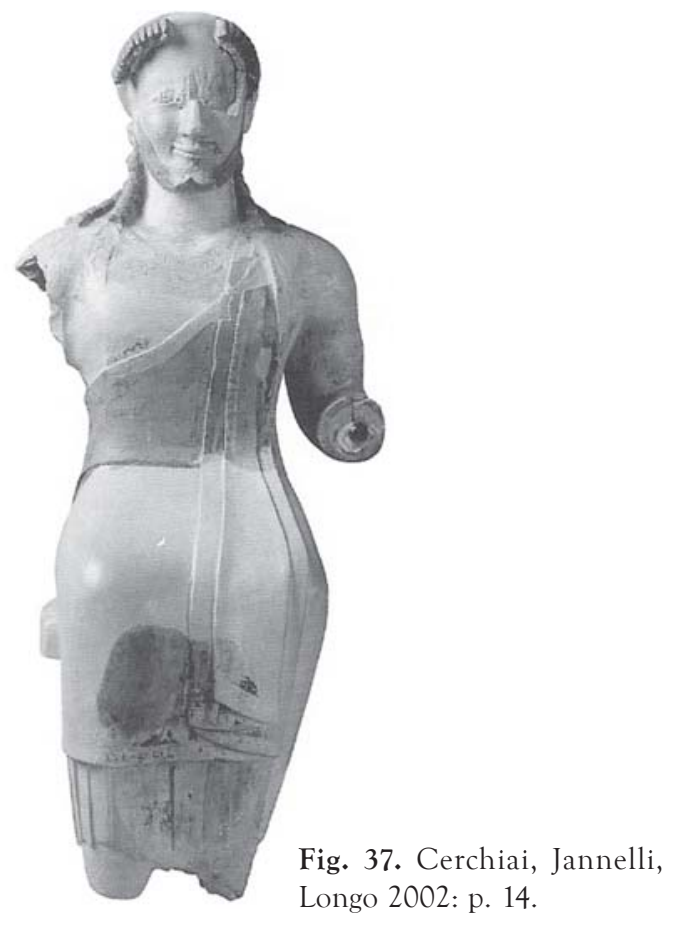

Mas são as esculturas de Zeus Keráunios o tipo predominante neste período. Esse padrão recebeu o nome Keráunios nos tempos modernos, com base na Iliada (V, 280; VII, 244; XVII, 516; XX, 438; XXII, 273) e na ode Olimpica (13, 77) de Píndaro. De acordo com G. Mylonas (1944: 148) a palavra keráunios nesses textos é utilizada quando se refere a Zeus como "aquele que lança o raio". Por isso, encontramos essa nomeação para as estátuas em que Zeus é representado em pé atirando um raio com a mão direita e segurando a águia com a mão esquerda.

O tipo de Zeus Keráunios, cuja representação foi uma invenção que se consolidou no século VI a.C., permaneceu sendo retratado em esculturas até o início do século $\mathrm{V}$ a.C. Conforme nos diz P. Themelis (2004: 148-149), o tipo de Zeus atirando o raio ocorre principalmente nas regiões gregas da Messápia, Ilíria, Épiro, Etólia, Élis-Olímpia e em áreas com traços culturais comuns com a Lócrida, Acaia e Messênia. Este tipo de representação foi também reproduzido em forma de estatuetas, tais como os ex-votos encontrados em santuários importantes de Zeus, como o do monte Liceu, de Dodona e de Olímpia (Tiverios 1997: 332).
P. Themelis (2004: 149) relaciona a origem desse tipo de representação com o Oriente. Segundo o pesquisador grego, há uma semelhança entre a representação de Zeus Keráunios e as estatuetas do deus sírio-palestino Reshef e que foram encontradas em vários santuários gregos. Além disso, uma estatueta de prata desse tipo de Zeus foi encontrada em Kallipeuke, na região do Baixo Olimpo, e que provavelmente é de origem hitita.

Como dissemos, essa representação de Zeus, encontrada em várias regiões do mundo grego, foi realizada em diversos materiais, desde a prata, bronze até em pedra calcária. Desse contexto citamos um exemplar desse tipo encontrado em Kition, na ilha de Chipre, cujo local representa a região mais oriental do mundo grego. Nessa peça de pedra calcária, que data de c. 500 a.C., Zeus é representado em pé, vestindo um himátion pelo corpo inteiro, atirando um raio com a mão direita. A posição do braço esquerdo indica a presença de uma águia (Fig. 38).

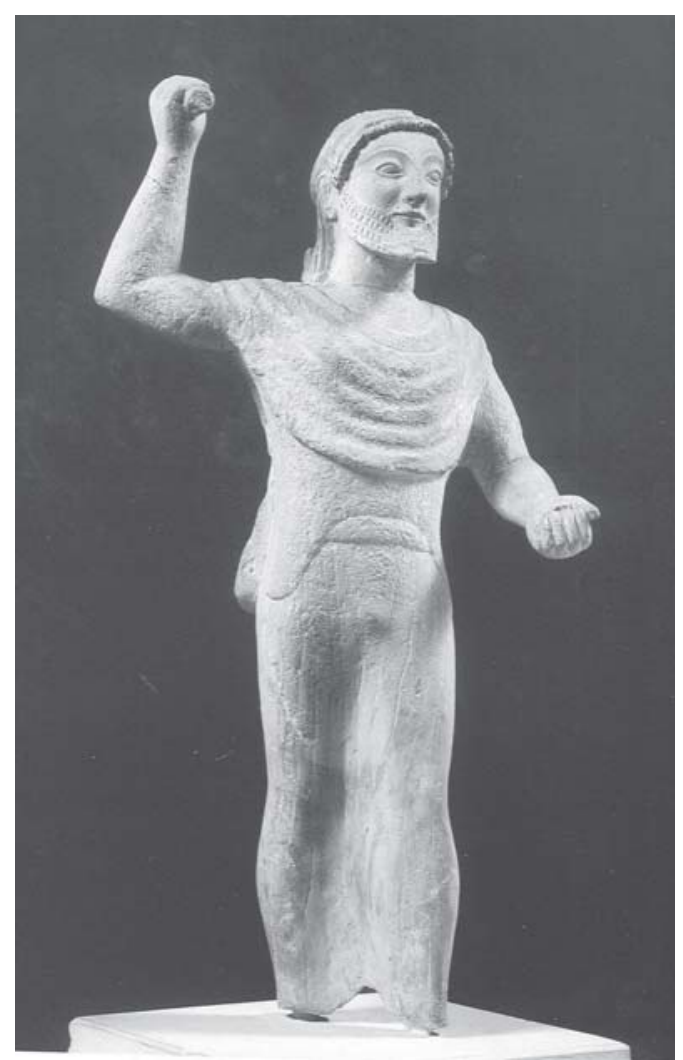

Fig. 38. Karageorghis 1998: p. 82. 
A próxima representação de Zeus Keráunios, que podemos citar, foi encontrada no santuário de Zeus em Olímpia e é datada de aproximadamente 480 a.C. Essa peça é feita em bronze e Zeus é retratado atirando um raio com a mão direita. $\mathrm{O}$ braço esquerdo estendido sugere a presença de uma águia, que não se conservou para a posteridade (Fig. 39). Segundo acredita P. Themelis (2004: 150), esse tipo pode ser originário de Olímpia e ter sido difundido às áreas da Messápia, do Épiro e da Ilíria, que foram colonizadas por Élis.

Esse tipo de representação continuou a ser utilizado na estatuária até ao menos a primeira metade do século $\mathrm{V}$ a.C. se aceitarmos a famosa estátua de bronze, encontrada no cabo de Artemísio na Eubéia, como uma imagem de Zeus (Fig. 40).

A ausência de atributos, que possam identificá-la a alguma divindade, e a posição dos braços tornou a estátua alvo de debates que a classificam como uma representação de Zeus ou Poseidon ou até mesmo a representação de um atleta. Georges Mylonas (1944: 155), que em um artigo levanta fortes evidências de que Zeus é a divindade representada na estátua. Mas acerca dessa escultura existe um debate sobre se era uma estátua de culto ou um ex-voto. Themelis (2004: 151) diz que o bronze não era o material

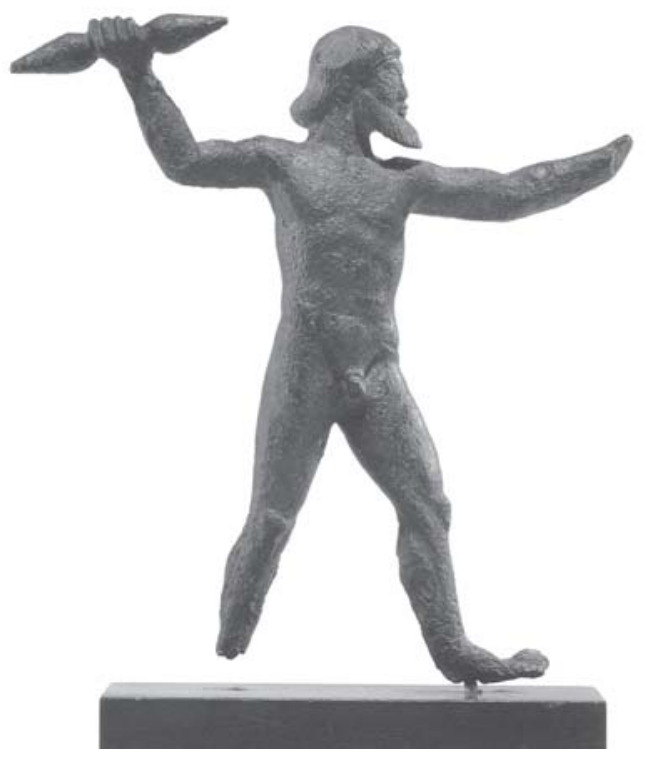

Fig. 39. Grassinger 2006: p. 74. utilizado para as estátuas de culto, mas o mármore ou marfim. A estátua de Artemísio é incompativel com o padrão de estátuas de culto do século $V$ a.C., que nesta época eram representadas de modo frontal para estabelecer uma relação direta com o fiel. Por isso, o autor considera que esta estátua é de natureza votiva.

O bronze de Artemísio é datado de c. 460 a.C. e seu estilo é distinto das outras esculturas de Zeus atirando o raio, datadas do início do século V a.C. Assim, vemos nesse exemplar, características da arte da época clássica tal como o realismo da representação humana.

O último exemplo do padrão de representação de Zeus atirando o raio (Keráunios), pertencente ao século $V$ a.C, é a pequena imagem encontrada gravada em um estrigilo de bronze encontrado no mar entre Siracusa e Leontinoi, na Sicília. Nessa peça, datada de aproximadamente 430 a.C., Zeus é representado nu em pé à direita, segurando um raio com a mão direita e a águia com a esquerda (Fig. 41). A imagem possui a inscrição $\Sigma$ OTEP atribuindo essa representação a Zeus Sóter (Salvador). É interessante notar que a imagem de Zeus foi gravada em um estrigilo, que era um instrumento utilizado pelos atletas para rasparem a areia, $\mathrm{o}$ suor e o óleo de oliva que se acumulava no corpo durante os treinos e/ou competições. A

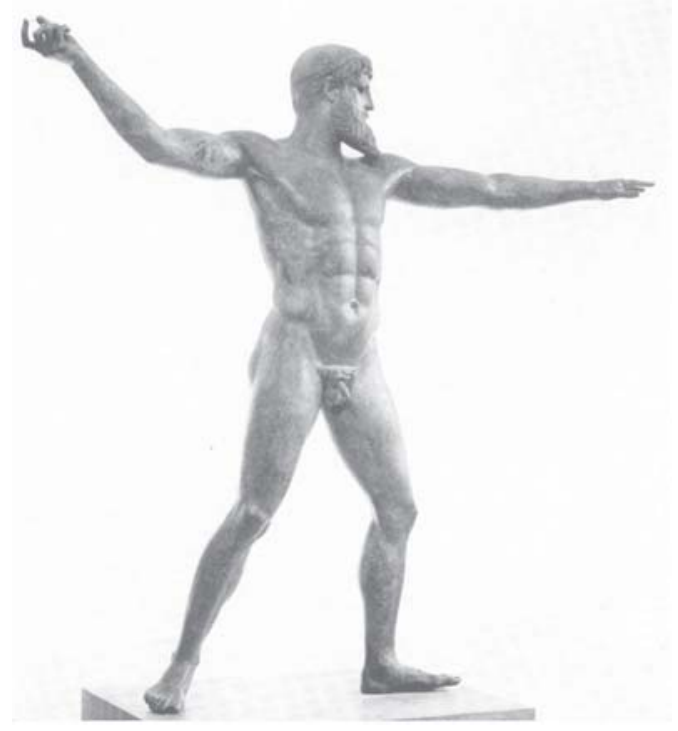

Fig. 40. http://commons.wikimedia.org/wiki/ Image:NAMA_Pos\%C3\%A9idon.jpg 
escolha de Zeus para a representação do estrigilo pode ser associada aos jogos olímpicos realizados em honra ao deus.

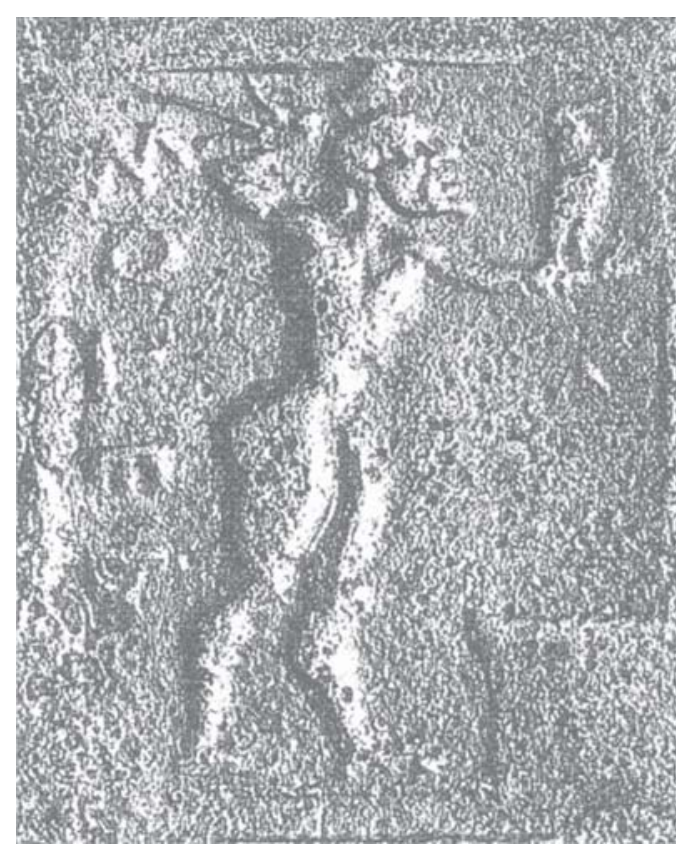

Fig. 41. Manganaro 2003: Fig. 10.

Dentre as representações de Zeus do século $V$ a.C., selecionadas para este estudo, destacamos dois relevos em que Zeus é retratado sentado. $\mathrm{O}$ exemplar mais antigo (c. 465 a.C.) é um relevo que pertence ao conjunto de métopas do templo de Hera em Selinunte, na Sićlia. Nessa peça, Zeus é representado sentado à esquerda com barba e cabelos curtos, vestindo um himátion e segurando a mão de Hera à direita (Fig. 42).

O segundo relevo é datado entre 438-432 a.C. e faz parte do friso leste do Pártenon, em Atenas, e Zeus também está representado junto à deusa Hera. Assim, o deus aparece sentado no trono (?) à esquerda com cabelos curtos e barba, vestindo um himátion, ao lado de Hera (Fig. 43).

Ao longo do levantamento das esculturas e relevos de Zeus, feitos no período clássico, notamos que durante a primeira metade do século $\mathrm{V}$ a.C. o deus foi pouco representado sentado no trono em relação às várias ocorrências do tipo de Zeus em pé atirando o raio (Keráunios).

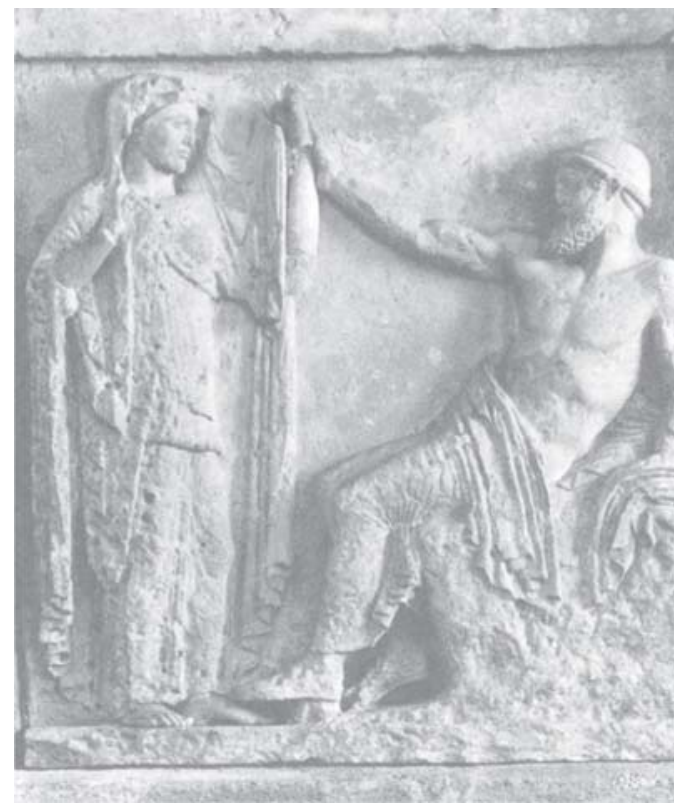

Fig. 42. Shefold 1986: p. 65.

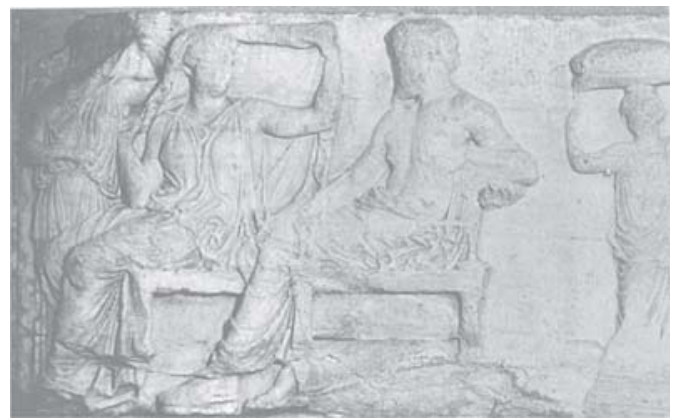

Fig. 43. Tournikiotis 1994: p. 127.

Segundo vários estudiosos, dentre eles M. Tiverios (1997: 334), o grande marco na representação de Zeus no período clássico sem dúvidas foi a estátua de Zeus Olímpico, obra de Fídias realizada para o templo de Zeus em Olímpia. O culto de Zeus em Olímpia teria ganhado um novo significado quando no ano de 430 a.C. foi colocada, na naos do templo, a estátua de ouro e marfim de Zeus Olímpico (Fig. 44). A estátua foi obra do escultor Fídias, que trabalhou no santuário após ter executado a estátua de ouro e marfim da deusa Atena no Pártenon. Segundo descreveu Pausânias (X, 9 11), o deus estava sentado no trono e era feito em ouro e marfim. Na sua cabeça existia uma 
coroa de brotos de oliveira e na sua mão esquerda a estátua segurava a deusa da vitória, Nike, igualmente feita em ouro e em marfim. Zeus Olímpico segurava em sua mão esquerda um cetro com uma águia sentada. Assim, diante das evidências arqueológicas e textuais podemos supor que a gigantesca estátua (12,37 metros de altura) tenha sido em parte responsável por consolidar o culto de Zeus no santuário (Gardiner 1925: 90).

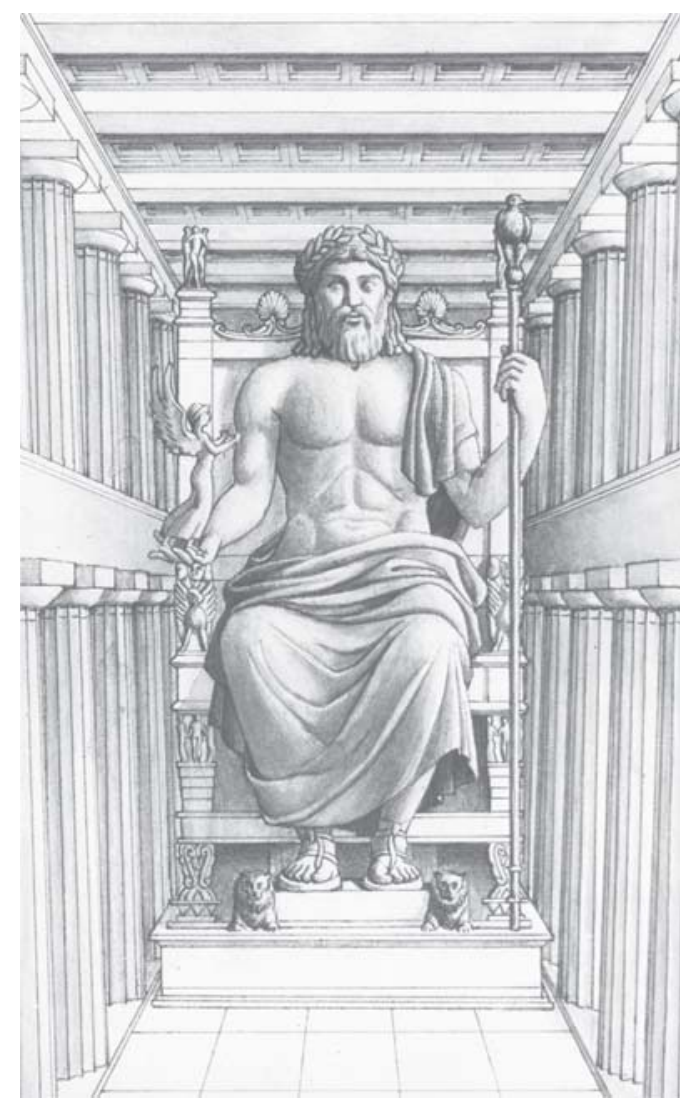

Fig. 44. Andronicos 1984: p. 26.

Tiverios (1997: 334) afirma que a estátua de Zeus Olimpico inevitavelmente influenciou artistas contemporâneos à obra de Fídias e também artistas posteriores à criação. Essa estátua de Zeus sentado no trono infelizmente não chegou aos dias atuais e sabemos de sua existência através de relatos e, dentre eles, o de Pausânias. Outras estátuas da divindade sentada, utilizada para o culto dentro de templos, foram feitas no século V a.C. e sabemos delas através das fontes textuais, como é o caso da estátua de Zeus Olímpico em Mégara (Pausânias, XL.2-4).

Diante disso, acreditamos que o padrão de representação de Zeus sentado no trono, nas esculturas, teria sido impulsionado pela estátua de Zeus Olímpico em Olímpia, sendo adotado em outras localidades a partir do final do século $\mathrm{V}$ a.C. No caso dos relevos, esse tipo de representação já era utilizado no início desse mesmo século, como vimos no relevo da métopa do templo de Hera em Selinunte.

Para o levantamento de esculturas e relevos feitos durante o século IV a.C. não foram encontrados esculturas da divindade que datem desse período, mas apenas cópias romanas de originais gregos. Por isso, nesse estudo citamos exemplos de relevos originais do século IV a.C.

Conforme nos diz I. Leventi (1997: 344), ao longo do século IV a.C. ocorreu uma divisão iconográfica em relação a Zeus: o deus foi retratado em pé - representando um herói e defensor - e sentado no trono - representando a sua majestade e seu poder divino. A estudiosa ressalta que neste período o deus foi raramente representado sozinho nas esculturas e relevos.

De acordo com C. Landwehr (2006: 123), no século IV a.C. se desenvolve a imagem de Zeus como deus-pai. A estudiosa afirma que esse tipo de representação se propagou rapidamente, popularizando a figura divina do deus e tornadoa mais corrente nos tempos helenísticos e romanos, permanecendo como exemplo séculos a fio.

A imagem de Zeus sentado no trono permanece como o padrão de representação do deus nos relevos do século IV a.C. O primeiro exemplar, de que dispomos, foi encontrado no teatro de Dioniso em Atenas e foi datado entre o século $\mathrm{V}$ e IV a.C. No relevo feito em mármore, Zeus aparece vestindo um himátion sentado à esquerda com cabelos curtos e barba, segurando com a mão esquerda um cetro; na cabeça um fillet (Fig. 45).

Outro relevo de Zeus, que podemos citar, foi encontrado em Corfu e é datado da segunda metade do século IV a.C. Nesse exemplar feito em mármore, Zeus aparece sentado em uma rocha à direita, ao lado de uma cobra, segurando um cetro com a mão esquerda e, com a mão direita, uma fiala (Fig. 46). 


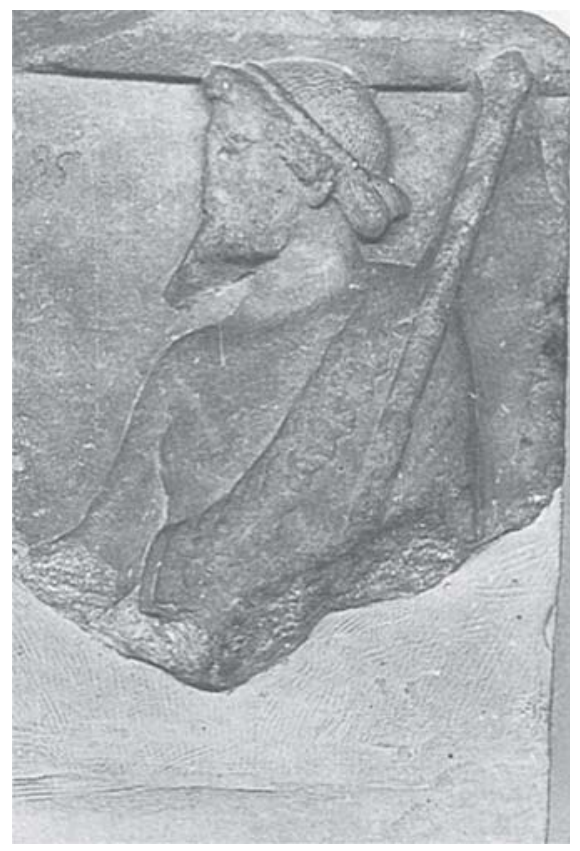

Fig. 45. LIMC (VIII): Fig. 149.

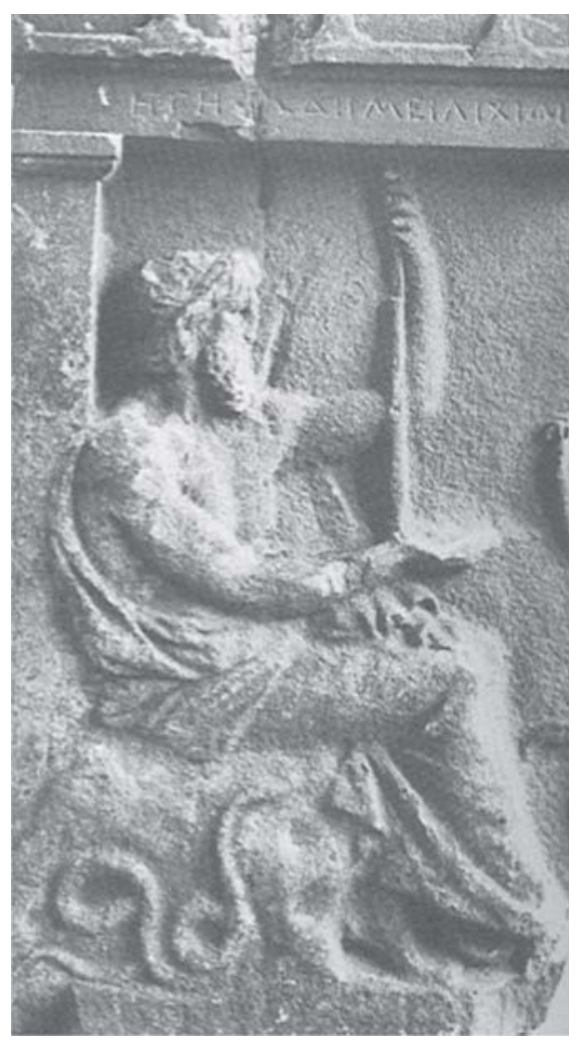

Fig. 46. LIMC (VIII): Fig. 202.
Esse relevo representa Zeus Meilichios que é relacionado a cultos de fertilidade. Conforme nos diz I. Leventi (1997: 344), relevos votivos representando Zeus Meilichios ocorrem, sobretudo, na segunda metade do século IV a.C. e na primeira metade do século III a.C., sendo o deus representado sentado no trono e segurando uma fiala. Como exemplo, temos o relevo encontrado no Pireu, datado dessa época, no qual o Zeus aparece no trono à direita, segurando um cetro com a mão esquerda e uma fiala com a mão direita (Fig. 47).

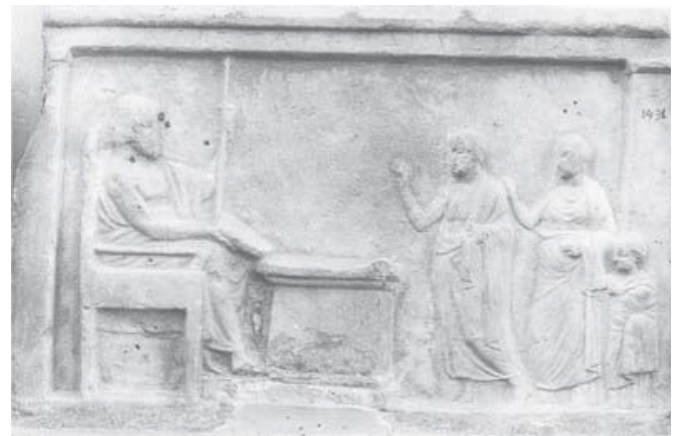

Fig. 47. LIMC (VIII): Fig. 200.

No Pireu também foi encontrado o relevo de Zeus Meilichios, onde o deus é representado reclinado à esquerda vestindo um himátion, segurando uma cornucópia com a mão direita e, com a esquerda, uma fiala (Fig. 48). Leventi afirma que a posição simposiasta de Zeus neste relevo é uma característica típica de divindades ctônicas e, a cornucópia é um símbolo de fertilidade raramente representado junto ao deus.

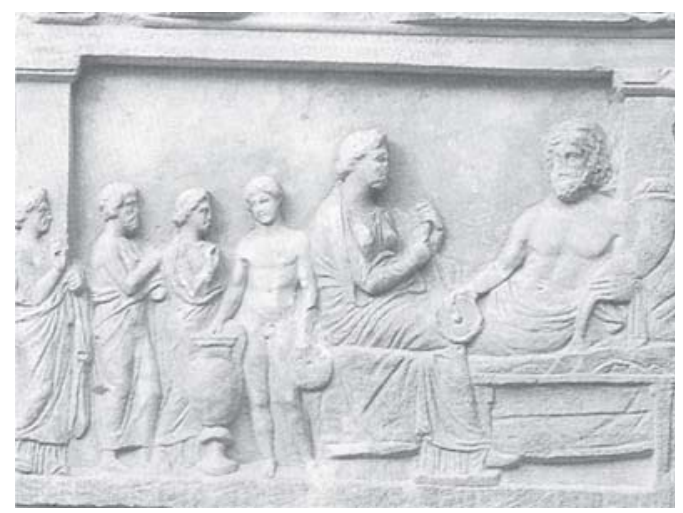

Fig. 48. LIMC (VIII): Fig. 210. 
Nos relevos datados da segunda metade do século IV a.C. (Figs. 46, 47 e 48) Zeus é representado com cabelos longos e cheios e barba longa e cheia. Acreditamos que essa mudança na imagem de Zeus - típica desse período - esteja relacionada com a imagem de Zeus como deus-pai. Esse tipo de representação de Zeus, com cabelos longos e cheios e barba cheia pode ser observada na cabeça de Zeus (Fig. 49) encontrada em Tarento, sul da Itália, datada do final do século IV a.C. Assim, esse é o padrão de representação de Zeus nas esculturas e relevos que permaneceu sendo utilizado no período helenístico.

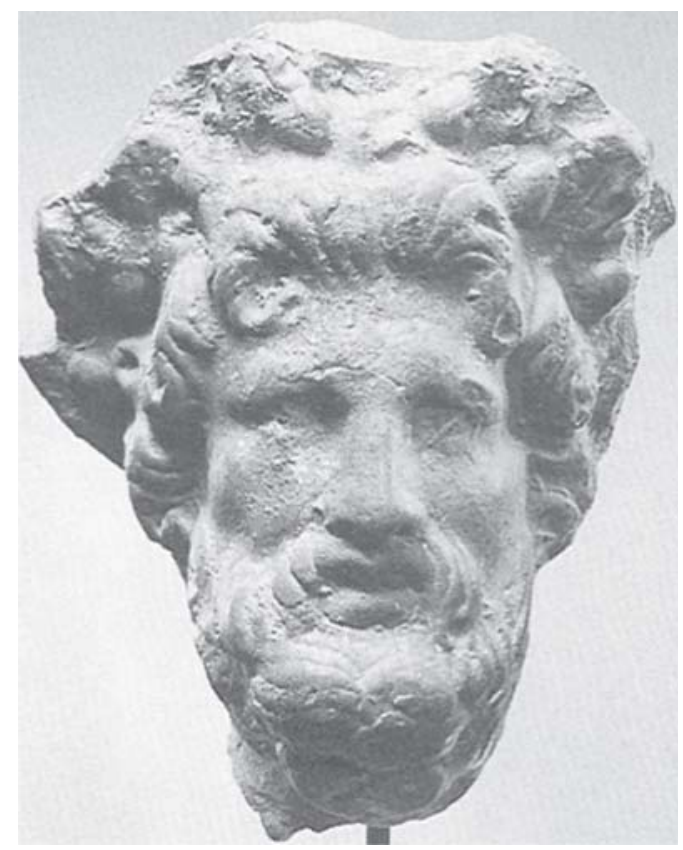

Fig. 49. LIMC (VIII): Fig. 218.

\section{Os tipos monetários de Olímpia e as esculturas e relevos de Zeus}

Para correlacionarmos as imagens de Zeus representadas em moedas com as imagens do deus representadas em esculturas e relevos, devemos apresentar a distinção existente entre esses dois tipos de suportes iconográficos.

De acordo com J. Spier (1990: 107), as imagens representadas em vasos pintados, em relevos e também em esculturas dos frisos dos frontões de templos, possuem um sentido narrativo, portanto, contam a passagem de uma história dentro de uma seqüência de tempo. Em contraste, as imagens representadas em moedas, gemas e em anéis possuem um significado emblemático - foram utilizadas como um símbolo de identificação -, portanto, são desprovidas de um sentido narrativo.

Assim, a especificidade desses suportes imagéticos norteia o modo como devemos analisar as imagens de Zeus nas moedas, esculturas e relevos.

Ao finalizarmos a contextualização histórica dos exemplares monetários e dos escultóricos notamos uma correspondência temporal nas imagens de Zeus em ambos os suportes, ou seja, o padrão de imagem utilizado nas moedas acompanha o padrão utilizado nas esculturas e relevos produzidos durante o período clássico.

Muitos autores costumam defender a dependência das chamadas artes menores (moedas, gemas e anéis) em relação às artes maiores (esculturas, relevos). Para eles os artistas responsáveis pelos desenhos das moedas eram influenciados pelo padrão de representação de esculturas e relevos do momento, assim como outros estudiosos acreditam na dependência da arte em relação aos textos. Mas atualmente muitos pesquisadores questionam essa dependência, levantando a hipótese de que a correspondência existente entre certos padrões artísticos em moedas e esculturas pode indicar uma idéia coletiva presente em uma determinada época a qual foi apropriada simultaneamente tanto pelos artistas das artes menores e das artes maiores, quanto pelos artistas visuais e literários.

Como vimos anteriormente, ao longo do século VI a.C. consolidou-se nas esculturas o padrão de imagem em que Zeus é representado em pé (atirando o raio) e sentado (no trono). A forma de representação do deus em pé permaneceu sendo utilizada até a primeira metade do século $\mathrm{V}$ a.C. como exemplificamos através da estátua de Zeus Keráunios de Chipre (Fig. 38), c. 500 a.C., do exemplar encontrado em Olímpia (Fig. 
39), datado de 480 a.C. e talvez da estátua de Artemíso (Fig. 40), datado de aproximadamente 460 a.C.

Nas moedas encontramos esse mesmo padrão de representação (em pé atirando o raio) e também a imagem de Zeus sentado no trono, nos tipos pertencentes ao século $\mathrm{V}$ a.C., sobretudo em emissões da Liga Arcádia (Figs. 5 e 6) e de Élis-Olímpia (Figs. 1, 2 e 7) no Peloponeso.

$\mathrm{Na}$ Sićlilia durante o século V a.C. vemos a imagem de Zeus em pé atirando o raio em moedas de Zancle (Fig. 3) e a imagem de Zeus sentado no trono em exemplares de Aetna (Figs. 9 e 10) e de Galária (Fig. 11).

Esses dois tipos de imagem de Zeus, que se cristalizaram como padrões para a sua representação no século VI a.C., foram adotados pelas primeiras emissões monetárias de Zeus no Peloponeso e na Sicília, conhecidas como as regiões que primeiro utilizaram a representação do deus em moedas. Anteriormente, vimos que a partir da segunda metade do século $\mathrm{V}$ a.C. esses padrões foram substituídos pela representação da cabeça de Zeus. Nesse sentido, a utilização das imagens de Zeus em pé e sentado em moedas da primeira metade do século $\mathrm{V}$ a.C. pode ser uma reminiscência do padrão de imagem estabelecido para a divindade no século VI a.C., que a partir da segunda metade do século $\mathrm{V}$ a.C. foram substituídos por um novo padrão nas moedas: a cabeça de Zeus.

Essa constatação deve ser atribuída, sobretudo, ao padrão de Zeus em pé atirando o raio, conhecido na estatuária como Zeus Keráunios, o qual deixou de ser o padrão de representação predominante tanto em moedas como nas esculturas e nos relevos da segunda metade do século V a.C. e em diante. Por outro lado, a representação de Zeus sentado no trono foi usada em algumas moedas do século IV a.C., nas emissões reais de Alexandre, o Grande (Fig. 16), datada de 331 a.C. e nas emissões de Creta (Figs. 13, 14 e 15), datadas entre 350 e 330 a.C.

É interessante notar que o tipo de Zeus sentado, que encontramos nas moedas do século V a.C., foram utilizados sobretudo em relevos de templo, como ocorreu no templo de Hera em Selinunte (Fig. 42) e do relevo do friso leste do Pártenon (Fig. 43).

Nessas representações Zeus não aparece sentado em um trono propriamente dito, mas em uma rocha e em um tipo de cadeira ou banco. Dentre as esculturas do século V a.C., sabemos de estátuas de culto em que Zeus foi representado sentado em um trono e que infelizmente não chegaram aos dias atuais. Talvez essas estátuas - que existiram até o final da Antiguidade - motivaram a representação desse tipo de imagem da divindade em moedas do final do século IV a.C.

Como dissemos, a representação de Zeus sentado no trono permaneceu como padrão utilizado nos relevos do século IV a.C. e pouco sabemos das esculturas de Zeus sentado, que remontam ao séculos $\mathrm{V}$ e IV a.C., pois não chegaram aos dias atuais.

Entretanto, uma associação entre as imagens da cabeça de Zeus em moedas com a cabeça de Zeus nos relevos permitiu-nos encontrar uma última correspondência entre os padrões de representação nos dois suportes iconográficos.

As duas únicas cabeças de Zeus emitidas em moedas no século $\mathrm{V}$ a.C foram cunhadas pela Liga Arcádia (Fig. 17) e por Élis em Olímpia (Fig. 18).

Nessas moedas vemos a representação da cabeça de Zeus com cabelos curtos e barba curta, correspondendo justamente ao padrão de representação de Zeus utilizado nos relevos do templo de Hera, em Selinunte, e do Pártenon, em Atenas. Essa correspondência também ocorre entre as cabeças de Zeus com cabelos compridos e barba comprida emitidas em moedas da segunda metade do século IV a.C. - em Olímpia, na Tessália, em Creta, na Macedônia, na Sicília e na Magna Grécia - e com a representação de Zeus nos relevos datados da segunda metade do século IV a.C. (Figs. 46, 47 e 48).

Assim, diante dessas considerações definimos uma seqüência cronológica do período clássico para a adoção dos tipos ou padrões de representação de Zeus em moedas, que corresponde aos padrões utilizados em esculturas e relevos (Tabela III). 


\section{Tabela III}

Século Va.C.

\begin{tabular}{ll}
\hline \multicolumn{1}{c}{ Moedas } & \multicolumn{1}{c}{ Esculturas / Relevos } \\
\hline \hline $\begin{array}{l}\text { Zeus em pé atirando o raio com a mão direita e } \\
\text { segurando a águia com a mão esquerda }\end{array}$ & $\begin{array}{l}\text { Zeus em pé (Keráunios) atirando um raio com a } \\
\text { mão direita e segurando, ou não, a águia com a } \\
\text { mão esquerda }\end{array}$ \\
$\begin{array}{l}\text { Zeus sentado no trono ou em rocha } \\
\begin{array}{l}\text { Zabeça de Zeus com coroa de folhas de oliveira, } \\
\text { cabelos curtos e barba curta }\end{array}\end{array}$ & $\begin{array}{l}\text { Cabeça de Zeus sem coroa de folhas de oliveira } \\
\text { com cabelos curtos e barba curta }\end{array}$ \\
\hline
\end{tabular}

Século IV a.C.

\begin{tabular}{|c|c|}
\hline Moedas & Esculturas / Relevos \\
\hline Zeus sentado no trono & Zeus sentado no trono \\
\hline $\begin{array}{l}\text { Cabeça de Zeus com coroa de folhas de oliveira, } \\
\text { cabelos curtos e barba curta ( } 1^{\text {a }} \text {. metade do } \\
\text { século IV a.C.) }\end{array}$ & $\begin{array}{l}\text { Lacuna existente devido à falta de documentação } \\
\text { (esculturas e relevos) original do período (1'a } \\
\text { metade do século IV a.C.) }\end{array}$ \\
\hline $\begin{array}{l}\text { Cabeça de Zeus com coroa de folhas de oliveira, } \\
\text { cabelos longos e barba longa ( } 2^{\text {a }} \text {. metade do } \\
\text { século IV a.C.) }\end{array}$ & $\begin{array}{l}\text { Cabeça de Zeus sem coroa de folhas de oliveira, } \\
\text { cabelos longos e barba longa (2a. metade do } \\
\text { século IV a.C.) }\end{array}$ \\
\hline
\end{tabular}

Essas foram as semelhanças (gerais) encontradas entre as representações de Zeus em moedas e as representações nas esculturas e relevos, que ocorreram ao longo do período clássico (século V e IV a.C.).

As influências dos tipos monetários de Zeus, batidos em Olímpia nas imagens do deus em esculturas e relevos do período, ao redor do mundo grego, não foram encontradas de forma significativa por este estudo. Concluímos que os padrões utilizados nas moedas de Olímpia não foram utilizados por esses tipos de suportes imagéticos. Acreditamos, no entanto, que houve uma influência das representações de Zeus das esculturas e relevos nas moedas no âmbito dos padrões gerais de representação da divindade, a saber, em pé, sentado e cabeça (cabelos e barba curta e cabelos e barba comprida). Sabemos disso porque, como vimos, os padrões de representação de Zeus em pé e sentado já eram utilizados muito antes de a imagem do deus começar a aparecer nas moedas. Eventualmente, essa influência nas moedas pode estar relacionada aos artistas (gravadores de cunho) responsá- veis pela criação das imagens monetárias, os quais seguiam os padrões de imagens das esculturas ou relevos. Podemos citar o caso da primeira imagem monetária de uma cabeça de Zeus emitida em Olímpia em 416 a.C., cujos traços estilísticos foram atribuídos por Seltman às esculturas da métopa do templo de Zeus (Seltman 1948: 71).

\section{Conclusão final}

Ao correlacionarmos as imagens de Zeus em moedas com as imagens do deus em esculturas e relevos, produzidas em época clássica, estabelecemos dois momentos importantes para a representação da divindade e que correspondem aos séculos deste período (séculos V e IV a.C.).

De um modo geral, consideramos o século $\mathrm{V}$ a.C. como o período de inovações na representação de Zeus. Durante essa fase, antigas imagens que remontam ao período arcaico, como a de Zeus Keráunios (em pé), foram trocadas tanto nas moedas como nas esculturas e relevos pela 
representação do deus sentado - pertencente ao período arcaico e que continuou a ser utilizada. Em relação às moedas foi também na segunda metade do século V a.C. que a cabeça de Zeus começou a ser representada.

Ainda que o nosso levantamento dos vasos não seja exaustivo, encontramos uma imagem de Zeus pertencente ao século $\mathrm{V}$ a.C. que revela como a representação de Zeus neste século ainda estava em vias de se consolidar (Fig. 50).

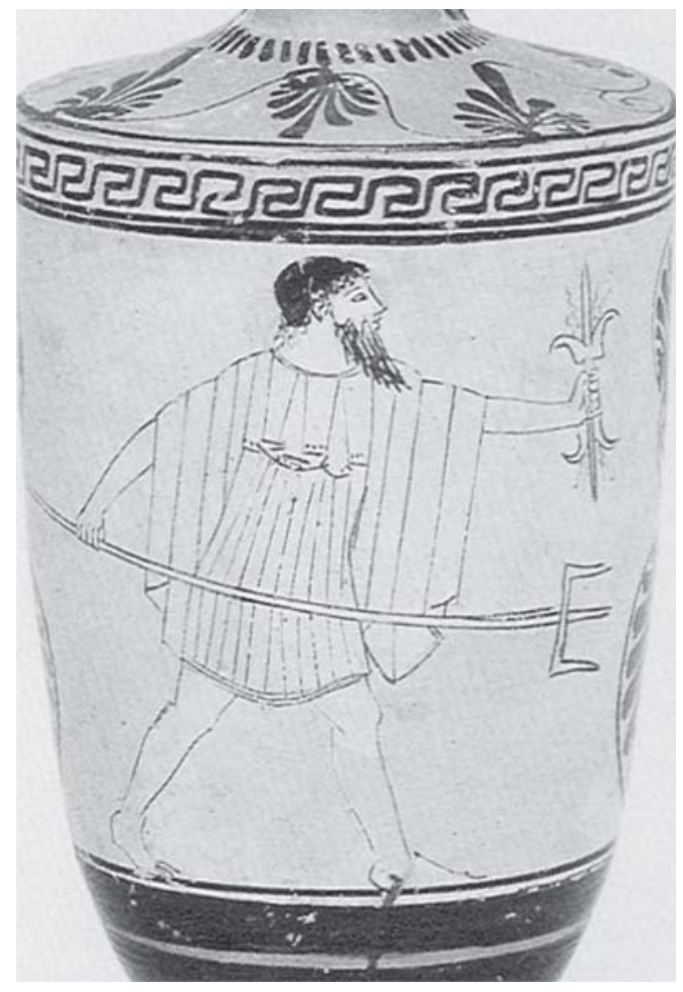

Fig. 50. LIMC (VIII): Fig. 75.

No lécito ático datado de 470 a.C. Zeus aparece segurando com a mão esquerda o raio, e, com a mão direita o tridente, conhecido como o principal atributo do deus Poseidon.

O século IV a.C. significou o período de consolidação da imagem de Zeus transformada no século anterior. Nos relevos vemos a permanência da representação de Zeus sentado no trono ou rocha assim como identificamos imagens do deus sentado em moedas datadas da segunda metade do século IV a.C. Nesta época as cabeças de Zeus representadas nas moedas foram desenhadas com cabelos cheios e compridos e barbas compridas da mesma forma que o deus foi representado nos relevos e nas esculturas do período.

Assim, diante de uma visão geral da representação de Zeus no período clássico vemos que até a primeira metade do século $\mathrm{V}$ a.C. predominou a imagem de Zeus em pé e atirando o raio nas moedas e nas esculturas. Esse tipo de representação indica o aspecto guerreiro de Zeus que remonta ao período arcaico. À medida que se chega à segunda metade do século $\mathrm{V}$ a.C. esse tipo de imagem é trocado pela imagem de Zeus sentado, que passou a ser utilizada tanto nas moedas e nas esculturas ao longo do século IV a.C. Essa posição de Zeus sentado e no trono é um indicativo de majestade e de poder consolidado. Nesse sentido, essa forma de representação associada aos cabelos compridos e barba comprida, que passou a acompanhar a imagem do deus, indica a consolidação de Zeus como o grande deus dos gregos. Lembremos que a arte tanto pode querer transmitir uma idéia em vias de se consolidar ou já consolidada.

Portanto, ao observarmos as formas de representação de Zeus em época clássica notamos elementos que nos levaram à compreensão de mudanças importantes no culto de Zeus neste período, sobretudo em relação à concepção de Zeus como o deus pai característica de seu culto no período helenístico.

Identificamos também dois centros principais, no Peloponeso, responsáveis por inovações na imagética de Zeus em moedas: as cidades responsáveis pelas emissões da Liga Arcádia e o santuário de Olímpia. De ambos os locais datam as representações mais antigas de Zeus em moedas assim como as primeiras representações monetárias da cabeça do deus.

Além disso, a utilização da águia parece ter sido uma invenção dos arcádios. De acordo com G. Mylonas (1944: 151-152), a águia não era mencionada nos textos homéricos (Iliada XI, 184; XII, 237) e nas odes de Píndaro (Píticas I) como um atributo de Zeus, mas era mencionada como uma ave que trazia um presságio. $\mathrm{O}$ autor relaciona essas antigas tradições literárias do norte grego com a ausência da águia nas estatuetas de Zeus Keráunios encontradas em Dodona, no 
Épiro. Essa representação de Zeus atirando um raio com a mão direita e segurando a águia com a mão esquerda apareceu primeiro no Peloponeso no século VI a.C.. Por isso, o autor sugere que talvez essa representação tenha surgido na Arcádia e no santuário do monte Liceu, onde a figura da águia parece ter sido representada nas estátuas do deus descobertas no local. Mylonas conclui que do monte Liceu, talvez, o uso da águia como um atributo de Zeus passou para Olímpia (Mylonas 1944: 152).

De fato, vemos o uso da águia como atributo de Zeus ora representada junto ao deus numa imagem ou ora representada sozinha no anverso ou reverso das moedas do santuário de Olímpia. Encontramos a imagem da ave também nas imagens monetárias do deus em cidades de regiões do Ocidente grego, como na Sicília e na Magna Grécia. Acreditamos que de Olímpia o uso da águia como atributo de Zeus em moedas e em esculturas e relevos foi difundido a outras áreas sob influência do mais notável centro dórico e ocidental do mundo grego.

Mas a águia não foi uma contribuição própria de Olímpia como acreditamos que tenha sido a coroa de folhas de oliveira vista nas representações de cabeças de Zeus em moedas do santuário e representada em praticamente todas as imagens de cabeças do deus em moedas do mundo grego batidas no período.

A coroa de folhas de oliveira é definida como um elemento menor que acompanha as representações de cabeças de Zeus em moedas. Consideramos que a coroa é uma representação específica do santuário de Olímpia, pois o exemplar mais antigo de cabeça de Zeus cunhado pela Liga Arcádia entre 428-418 a.C não possui a imagem da coroa feita com os ramos da árvore. A representação monetária de uma cabeça de Zeus com coroa de folhas de oliveira foi encontrada em Olímpia e é datada de 416 a.C.

O kótinos, como era chamada a coroa de folhas de oliveira em Olímpia, era o único prêmio concedido aos atletas pela vitória nos jogos olímpicos. Conforme lembra N. Yalouris (2004: 125), o ramo de oliveira selvagem era sempre cortado da mesma antiga árvore de oliveira, denominada kallistéphanos (bela coroa), que crescia à direita do opisthodomos do templo de Zeus. Um jovem, cujos pais ainda vivessem, utilizando uma tesoura de ouro, cortava da árvore a quantidade exata de ramos equivalente ao número de competições. Com eles em mãos, esse mesmo jovem penetrava no templo de Hera e colocava-os sobre uma mesa feita de ouro e marfim. E assim, deste local eram retirados pelos hellanodíkai ${ }^{7}$ para coroar os vencedores. Acreditava-se também que as árvores de oliveiras selvagens brotaram da oliveira plantada por Héracles no terreno do santuário, que as teria trazido do país dos hiperbóreos.

Nesse sentido, vemos que a coroa feita de ramos de oliveira é também um símbolo dos jogos olímpicos e, portanto, um símbolo de vitória. Nos jogos realizados em outros santuários gregos a coroa era feita com ramos de outras árvores. Em Delfos, nos jogos píticos, a coroa era feita com folhas de louro, em Neméia a coroa era feita com ramos de pinheiro. A coroa feita de folhas de carvalho é um símbolo de Zeus de Dodona.

Assim, em todas as representações de cabeças de Zeus em moedas da Sicília, Magna Grécia e de Creta a coroa de folhas de oliveira compõe esse tipo de imagem. Por isso, de todos os elementos menores que foram representados junto ao deus (raio, águia, cetro), a coroa de folhas de oliveira é o único tipo de imagem que podemos afirmar que é originário de Olímpia e que foi apropriado por outras áreas do mundo grego. A difusão desse elemento limitou-se apenas às moedas, pois não foram encontrados em representações da divindade nas esculturas e relevos do período clássico.

Talvez essa constatação se deva ao fato de que não encontramos esculturas e relevos de Zeus típicas do culto em Olímpia. As fontes textuais relataram estátuas de Zeus Olímpico que eram veneradas em Siracusa, em Mégara e em Esparta e talvez nessas esculturas estivesse representado o padrão próprio da representação que vemos nas moedas de Olímpia; o culto

(7) "Árbitros dos jogos", eram escolhidos para uma olimpíada e recebiam um treinamento por um período de dez meses (Yalouris 2004: 122). 
influiu no padrão de representação. Além disso, muitas imagens em relevo de Zeus estão desgastadas o que dificultou a busca de certos padrões, como a coroa de folhas de oliveira.

A estátua de Zeus Olímpico realizada por Fídias em aproximadamente 430 a.C. permanece como a maior contribuição do santuário de Olímpia na fixação figurativa de Zeus na Grécia antiga. $\mathrm{O}$ aspecto sentado e enorme do deus, vistos nesta estátua, podem indicar que o culto de Zeus como o deus máximo havia se firmado entre os gregos. A obra influiu tanto na representação do deus nas esculturas como em moedas posteriores.
Assim, as imagens de Zeus nas moedas de Olimpia - que provavelmente foram escolhidas para representar todos os gregos - contribuíram para a consolidação de uma representação específica da divindade utilizada em moedas gregas até o final do período helenístico.

\section{Agradecimentos}

Agradeço à FAPESP pelo financiamento da pesquisa (2005-2007) que dedico à minha orientadora, Profa. Dra. Maria Beatriz Borba Florenzano.

LAKY, L.A. The coins of Olympia and the consolidation of Zeus' imagetic in Classical Greece. Revista do Museu de Arqueologia e Etnologia, São Paulo, 18: 211-237, 2008.

\begin{abstract}
The aim of this article is to present a study of the monetary iconography of the coins minted by the poleis that controlled the sanctuary of Olympia during the fifth and fourth centuries B.C. Our intention is to understand how these coins can contribute to the consolidation of Zeus' visual representation. For that purpose we compared the images of Zeus and his attributes on these coins with the same images of the deity on coins issued by other poleis and in sculptures and reliefs. We concluded that the Peloponnesus was the center of innovation of Zeus' imagetic, disseminating a characteristic pattern mainly to the Western poleis. The systematization of the pattern of Zeus' representation in sculptures and reliefs allowed the definition of a chronology for the representation of Zeus on Greek coins and revealed a well defined historical context for the cult of the god.
\end{abstract}

Keywords: Olympia - Zeus - Monetary iconography.

\title{
Referências bibliográficas
}

\section{ANDRONICOS, M.}

1993 Olimpia, il sito archeologico e il museo. Atenas: Ekdotike Athenon.

BÉRARD, C.; DURAND, J.-L.

1984 Entrer en imagerie. In: Vernant, J.-P (Ed.) La cité des images, religion et societé en Grèce Antique. Lausanne, Fernand Nathan LEP: $19-34$.
BERVE, H.; GRUBEN, G.

1963 Greek temples, theatres and shrines. Londres: Thames and Hudson.

BREITENSTEIN, N.; SCHWABACHER, W.

1981 Sylloge Nummorum Graecorum: The Royal Collection of Coins and Medals, Danish National Museum (SNGCop). Vol. 1 e 3. Copenhagen: Ed. West Milford; N. J: Sunrise Publications. 
CALLATÄY, F.; GITLER, H.

2004 The Coin of Coins. Jerusalem: The Israel Museum.

CERCHIAI, L.; JANNELLI, L.; LONGO, F.

2002 The Greek cities of Magna Graecia and Sicily. Los Angeles: Getty Publications.

COOK, A.B.

1925 Zeus: A study in Ancient Religion. Cambridge: Cambridge University Press.

DOWDEN, K.

2006 Zeus. N. York, Londres: Routledge.

ELDERKIN, G.W.

1940 Bronze statuettes of Zeus Keraunios. AJA, 44 (2): 225-233.

ESTRABÃO

1960 The Geography. Tradução de Horace Leonard Jones. Cambridge, Mass: The Loeb Classical Library; Londres: Harvard University Press.

FISCHER-HANSEN, T.; NIELSEN, T.H.; AMPOLO, C.

2005 Sikelia (s.v.). In: Hansen, H.H.; Nielsen, T.H. (Orgs.) An Inventory of Archaic and Classical Poleis. Oxford: Oxford University Press.

FLORENZANO, M.B.B.

2000 Entre reciprocidade e mercado: a moeda na Grécia antiga. Tese (Livre Docência) São Paulo: Museu de Arqueologia e EtnologiaUSP.

GARDINER, N.

1925 Olympia, its history and remains. Oxford: The Clarendon Press.

GARDNER, P.

1963a The British Museum Catalogue (BMC). A Catalogue of Greek Coins. Peloponnesus. Bolonha: Arnaldo Forni Editore.

1963b The British Museum Catalogue (BMC). A Catalogue of Greek Coins. Thessaly to Aetolia. Bolonha: Arnaldo Forni Editore.

GRASSINGER, D.; PINTO, T.O., SCHOLL, A. (Orgs.)

2006 Deuses Gregos - Coleção do Museu Pergamon de Berlim.São Paulo: FAAP.

HALL, J.

2001 Quem eram os gregos. Revista do Museu de Arqueologia e Etnologia 11: 213-225.

HANSEN, H. H.; NIELSEN, T.H. (Orgs.)

2005 An Inventory of Archaic and Classical Poleis. Oxford: Oxford University Press.

HEAD, B.

1963 Historia Numorum, a manual of Greek numismatics. Londres: Spink \& Son LTD.

HOLANDA, A.B.

1975 Novo Dicionário Aurélio. Rio de Janeiro: Editora Nova Fronteira.
HOMERO.

2004 Ilíada. Tradução de Carlos Alberto Nunes. Rio de Janeiro: Ediouro.

KARAGEORGHIS, V.

1998 Greek Gods and Heroes in Ancient Cyprus. Atenas: Commercial Bank of Greece.

KRAAY, C. M.

1976 Archaic and Classical Greek Coins. Londres: Methuen.

LANDWEHR, C.

2006 Zeus, Poseidon, Hades - os deuses paternos. In: Grassinger, D.; Pinto, T.O.; Scholl, A. (Orgs.) Deuses Gregos - Coleção do Museu Pergamon de Berlim. São Paulo: FAAP.

LEVENTI, I.

1997 Classical Period II: 4 th Centh. B.C. In: Lexicon Iconographicum Mythologiae Classicae (LIMC). Vol. VIII (1 e 2). Thespiades - Zodiacus et Supplementum Abila - Thersites. Düsseldorf, Zürich: Artemis Verlag. Lexicon Iconographicum Mythologiae Classicae (LIMC).

1997 Vol. VIII (1 e 2). Thespiades - Zodiacus et Supplementum Abila - Thersites. Düsseldorf, Zürich: Artemis Verlag.

MANGANARO, G.

2003 Ancora sui culti della Sicilia greca: Zeus Sóter e il fiume Sichas. Rivista Svizzera di Numismatica, 82: 5-15.

MARINATOS, N.; HÄGG, R. (Eds.)

1993 Greek Sanctuaries. New Approaches. Londres, N. York : Routledge.

MILDEBERG, L.; HURTER, S.

1985 The Arthur S. Dewing collection of Greek coins - Ancient coins in North American Collections (ANS). N. York: The American Numismatic Society.

MORGAN, C.

1994 Athletes and Oracles - The transformation of Olympia and Delphi in the eighth century B.C.. Cambridge: Cambridge University Press.

MYLONAS, G.

1944 The bronze statue from Artemision. Hesperia, 48 (2): 143-160.

NICOLET-PIERRE, $\mathrm{H}$.

1975 Remarques sur la chronologie relative des plus anciennes séries de stateres éléens. RN, $17: 6-17$.

PARKE, H.W.

1967 The oracles of Zeus. Dodona, Olympia, Ammon. Cambridge, Massachusetts: Harvard University Press. 


\section{PAUSÂNIAS.}

1954 Description of Greece. Tradução de W. H. S. Jones e H. A. Ormerod. Londres: William Heinemann; Cambridge: Harvard University Press.

\section{PÍNDARO.}

1969 The Odes. Tradução de C.M. Bowra. Londres: Penguin Books.

\section{RICHTER, G.M.A.}

1968 A Handbook of Greek Art. Londres: The Phaidon Press.

SEAR, D.

1978 Greek Coins and their values. Londres: Seaby.

SELTMAN, C.T.

1921 The Temple Coins of Olympia. Cambridge: Cambridge University Press.

1948 Greek Sculpture and Some Festival Coins. Hesperia, 17 (2): 71-85.

SHEFOLD, K.

1986 Grécia Clássica. Lisboa: Editorial Verbo.

SHIPLEY, G.

2005 Messenia (s.v.). In: Hansen, H.H.; Nielsen, T.H. (Orgs.) An Inventory of Archaic and Classical Poleis. Oxford: Oxford University Press.

SPIER, J.

1990 Emblems in Archaic Greece. BICS (31): 107-129.

STILLWELL, R. (Ed.).

1976 The Princeton Encyclopedia of Classical sites. Princeton: Princeton University Press.

THEMELIS, P.

2007 Cults on Mont Ithome. Kernos, 17 : 143-154.
TIVERIOS. P.

1997 Early times to 5 th centh. B.C. In: Lexicon Iconographicum Mythologiae Classicae (LIMC). Vol. VIII (1 e 2). Thespiades - Zodiacus et Supplementum Abila - Thersites. Düsseldorf, Zürich: Ártemis Verlag.

TOURNIKIOTIS, P. (Org.)

1994 The Parthenon and its impact in Modern Times. Atenas: Melissa Publishing House, G. Rayas \& Co.

VERNANT, J.P (Ed.)

1984 La cité des images, religion et societé en Grèce Antique. Lausanne: Fernand Nathan LEP.

WALKER, A.

2004 Sanctuary: Elean Coins of Olympia. Minerva, 15 (4): 27-30.

WILLIAMS, R.T.

1965 The Confederate Coinage of the Arcadians in the Fifth Century B.C. N. York: The American Numismatic Society.

WROTH, W.

1963 The British Museum Catalogue (BMC). A Catalogue of Greek Coins. Crete to Aegean Islands. Bolonha: Arnaldo Forni Editore.

YALOURIS, N.

1976 Olympia. In: Stillwell, R. (Ed.) The Princeton Encyclopedia of Classical sites. Princeton: Princeton University Press.

YALOURIS, N. (Org.)

2004 Os Jogos Olimpicos na Grécia antiga. São Paulo: Odysseus. 